NBER WORKING PAPER SERIES

\title{
HAS GLOBAL AGRICULTURAL TRADE BEEN RESILIENT UNDER COVID-19? FINDINGS FROM AN ECONOMETRIC ASSESSMENT OF 2020
}

\author{
Shawn Arita \\ Jason Grant \\ Sharon S. Sydow \\ Jayson Beckman \\ Working Paper 29551 \\ http://www.nber.org/papers/w29551 \\ NATIONAL BUREAU OF ECONOMIC RESEARCH \\ 1050 Massachusetts Avenue \\ Cambridge, MA 02138 \\ December 2021
}

\begin{abstract}
Versions of this paper were invited for presentation at the 2020 International Agricultural Trade Research Consortium (IATRC) Annual Meeting and the NBER Spring 2021 Conference on Risks in Agricultural Supply Chains, hosted by NBER and the Economic Research Service of the U.S. Department of Agriculture. The authors are grateful for the discussion and helpful comments from Pol Antras, David Zilberman, Wyatt Thompson, Thomas Hertel, Ian Sheldon, Kari Heerman, Titus Awokuse, Joseph Cooper, Callie McAdams, Mirvat Sewadeh, Patricia Deal and participants at the IATRC and NBER conferences. All remaining errors are our own. The views expressed here are those of the authors and do not reflect the views of the Office of the Chief Economist, the Economic Research Service or U.S. Department of Agriculture. The views expressed herein are those of the authors and do not necessarily reflect the views of the National Bureau of Economic Research.
\end{abstract}

NBER working papers are circulated for discussion and comment purposes. They have not been peer-reviewed or been subject to the review by the NBER Board of Directors that accompanies official NBER publications.

(C) 2021 by Shawn Arita, Jason Grant, Sharon S. Sydow, and Jayson Beckman. All rights reserved. Short sections of text, not to exceed two paragraphs, may be quoted without explicit permission provided that full credit, including $\odot$ notice, is given to the source. 
Has Global Agricultural Trade Been Resilient Under Covid-19? Findings from an Econometric Assessment of 2020

Shawn Arita, Jason Grant, Sharon S. Sydow, and Jayson Beckman

NBER Working Paper No. 29551

December 2021

JEL No. F13,F14,Q17,Q18

\begin{abstract}
Global agricultural trade, which increased at the end of 2020, has been described as "resilient" to the impacts of the COVID-19 coronavirus pandemic; however, the size and channels of its quantitative impacts are not clear. Using a reduced-form, gravity-based econometric model for monthly trade, we estimate the effects of COVID-19 incidence rates, policy restrictions imposed by governments to curb the outbreak, and the de facto reduction in human mobility/lockdown effect on global agricultural trade through the end of 2020. We find that while agricultural trade remained quite stable through the pandemic, the sector as a whole did not go unscathed. First, we estimate that COVID-19 reduced agricultural trade by the approximate range of 5 to 10 percent at the aggregate sector level; a quantified impact two to three times smaller in magnitude than our estimated impact on trade occurring in the non-agricultural sector. Second, we find sharp differences across individual commodities. In particular, we find that non-food items (hides and skins, ethanol, cotton, and other commodities), meat products including seafood, and higher value agri-food products were most severely impacted by the pandemic; however, the COVID- 19 trade effect for the majority of food and bulk agricultural commodity sectors were found to be insignificant, or in a few cases, positive. Finally, we also examine the effects across low vs high income countries, the changing dynamics of the pandemic's effect on trade flows, and the effects along the extensive product margins of trade.
\end{abstract}

Shawn Arita

Office of the Economist

United States Department of Agriculture

Washington, DC

shawn.arita@usda.gov

Jason Grant

Virginia Tech

Blacksburg, VA

jhgrant@vt.edu
Sharon S. Sydow

Office of the Economist

United States Department of Agriculture

Washington, DC

sharon.sydow@usda.gov

Jayson Beckman

Economic Research Service

United States Department of Agriculture

Washington, DC

Jayson.Beckman@usda.gov 


\section{INTRODUCTION}

In 2020, the world economy suffered an immediate and significant global recession brought on by the coronavirus (COVID-19) pandemic. Global gross domestic product (GDP) shrank 3.2 percent (International Monetary Fund (IMF), 2021). In response to disease outbreaks, many national and sub-national governments had imposed lockdowns, stay-at-home orders, and the promotion of remote business and education activities to thwart the spread of the virus. These actions contributed to significant disruptions of non-essential businesses including restaurants, bars, shopping centers, and attractions. ${ }^{1}$ Service and tourism industries have been particularly hard hit. For example, the year-over-year percentage change in weekly airline traffic plunged well over 50 percent for most industrialized nations in 2020 compared to $2019 .^{2}$ However, as countries have learned to manage the crisis, GDP forecasts for global economic growth in 2021 and 2022 have become more optimistic with forecasts of 6 and 4.9 percent growth, respectively (IMF 2021). ${ }^{3}$

In the early phases of the pandemic, initial 2020 forecasts for world trade were bleak. In April 2020, the World Trade Organization (WTO) forecasted declines in the value of real exports of -8.1 percent, -16.5 percent and -20.4 percent under a V- (optimistic), U- (less optimistic), and L-shaped (pessimistic) set of economic recovery scenarios, relative to a baseline without pandemic (WTO 2020a). ${ }^{4}$ However, even the most optimistic scenario turned out to overstate the actual decline in total trade in 2020, which according to the WTO, was -5.3 percent (WTO 2021). ${ }^{5}$ The WTO identified several reasons for the better-than-expected trade performance in 2020, including strong monetary and fiscal policies in many governments, business and household innovation and adaptation that helped stabilize economic activity, and trade policy restraint (WTO 2021). While some trade restrictive measures were initially introduced when the pandemic began, including export restrictions for cereals, most of these measures were rescinded and new restrictions were not imposed. Countries also introduced trade facilitating measures in response to the pandemic, such as lowering import tariffs or taxes (Evenett et. al. 2021).

Global trade in food and agricultural products also outperformed the WTO's initial projections, growing 3.5 percent in 2020. The smaller impact of the pandemic on global agricultural trade is likely related to several factors including a low-income elasticity of food demand, shipping channels that do not require substantial human interaction (i.e., bulk commodities), and the essential nature of the industry that many governments declared. Indeed, the WTO (2020b) describes agricultural trade during the COVID-19 pandemic as a "story of resilience" and one of the few "bright spots" in the global economy. Nevertheless, global food insecurity rose during the pandemic, with FAO estimating that 768 million people were facing hunger in 2020, 118 million more people than in 2019 (FAO et al., 2021).

\footnotetext{
${ }^{1}$ Experience with similar diseases (i.e., SARS, MERS, H1N1) reveals that while the human costs can be significant, the economic toll is due to the preventive behavior of individuals and the transmission control policies of governments (Brahmbhatt and Dutta, 2008).

${ }^{2}$ Flight data provided by Statista: https://www.statista.com/statistics/1104036/novel-coronavirus-weekly-flights-change-airlinesregion/

${ }^{3}$ It should be noted that prior outlooks forecasted a larger contraction in GDP. In June 2020, the World Bank forecasted a 5.2-percent decline in global GDP growth; the International Monetary Fund (IMF 2020) projected a 4.2-percent decline. The World Bank forecasts growth of 5.6\% in 2021 and $4.3 \%$ in 2022.

${ }^{4}$ For agricultural exports, the projected decline was -6.5 percent, -11.2 percent, and -12.7 percent, respectively.

${ }^{5}$ According to its latest projections, the WTO forecasts a growth in trade of $8.0 \%$ in 2021 and $4.0 \%$ in 2022 .
} 
While descriptive analyses may shed some light on the trade flow impacts of the pandemic, simple year-over-year changes is clouded by other confounding factors including ongoing animal disease challenges related to African Swine Fever (ASF) in pork and swine production, burgeoning feed demand by China related to a faster than expected recovery of its hog herd, policy changes such as the U.S.-China Phase One trade agreement, and other factors. While global agricultural trade registered an overall increase in 2020, it is unclear to what extent COVID-19 affected trade flows conditional on other confounding factors. Identifying the pandemic effect from other factors is the key empirical objective of this paper.

A few studies have investigated the impacts of COVID-19 on international trade. Mallory (2020) analyzed early 2020 monthly data and found that beef and pork markets were temporarily impacted by lower exports during the initial onset of COVID-19, whereas grains and oilseeds markets were not affected. Friedt and Zhang (2020) estimate that the pandemic reduced Chinese exports by $40-45$ percent during the initial wave. The authors estimate that China's domestic supply shocks contributed about 10-15 percent of the total reduction in Chinese exports, while international import demand shocks reduced the propensity of countries' purchases of Chinese exports by only 5-10 percent. Kejzar and Velic (2020) characterize the impacts of COVID-19 on supply chains in terms of the relative upstream or downstream position of an industry. Recently, Beckman and Countryman (2021) found that agricultural trade increased by 2.3 percent in 2020; but the information they present is at a highly aggregated level—and only accounts for total 2020 trade, without providing the decomposition done here. Arita, Grant and Sydow (2021) provided a preliminary "early look" assessment of the impacts on agricultural trade using quarterly countrylevel data on imports of agricultural and non-agricultural commodities in a non-directional framework using data through August 2020. This paper builds off this analysis by using a more rigorous bilateral estimation framework across disaggregated agricultural commodities and market regions, adds non-agricultural and manufacturing trade to the analysis, and includes a longer time period (complete 2020 calendar year).

This article provides a comprehensive ex post quantitative assessment of the impacts of COVID19 on food and agricultural trade. Specifically, we develop a monthly reduced form, gravitybased model of bilateral agricultural and non-agricultural trade and econometrically assess different dimensions of the global pandemic effect. We examine the extent to which COVID-19 affected bilateral trade in 2020 relative to the pre-pandemic era, using high frequency monthly data and detailed agricultural product sectors to account for the heterogeneous impact of the pandemic on economic outcomes and differences in underlying requirements of product distribution. As the governmental response to the pandemic was diverse and many countries experienced several surges of COVID-19 infections, we leverage variation in country-specific mobility restrictions and national lockdown stringency to identify trade impacts. To the best of our knowledge, this study is the first to systematically quantify the differential impacts of the pandemic on agricultural versus non-agricultural trade using a full calendar year of monthly data.

Our analysis aims to unpack various components of the COVID-19 pandemic effect on trade and is organized as follows. First, we examine the impacts of the overall agricultural sector and compare them to quantified impacts on the non-agricultural sector. Our estimated pandemic effect is decomposed between COVID-19 incidence rates, policy restrictions, de facto reduction in human mobility/lock-down effects and further between import demand and export supply disruptions. Second, we disaggregate impacts across product-types and stratify which products were most affected by the pandemic compared to product sectors that were unaffected or even 
benefited from its indirect effects. Third, we illustrate the differential impact of the pandemic across countries with differing development levels and income classification, highlighting in particular the more severe impacts on low-income countries. Fourth, our analysis examines how the pandemic impacts on trade may have shifted throughout the year as industries learned to operate within the health and safety guidelines necessitated by the pandemic. Finally, we examine the pandemic's impact on the extensive margin of trade using monthly U.S. port level shipments.

Potential impacts of trade restricting and trade facilitating policy responses to the pandemic were not incorporated into this analysis, although we believe that any positive or negative effects these measures had on agricultural trade during the period were likely minimal. First, these measures covered a relatively small share of total agricultural and food trade. Evenett et. al. (2021) estimate that export restraints applied to agriculture and food trade during January-October 2020 covered $\$ 39.4$ billion (3\%) of total 2019 trade, while import reforms covered $\$ 42.2$ billion (4\%). Second, Evenett et. al. (2021) found that trade policy intervention in food trade was not as geographically widespread and more likely to be temporary relative to medical products and personal protective equipment (PPE), which accounted for almost all of the COVID-19-related trade policy responses. Third, relatively stable food supplies and prices prior to the pandemic likely reduced the broad, open-ended use of export controls as observed in earlier periods (e.g., 2007/08 and 2010/11) when grain stocks were low, and prices spiked. Heterogeneous trade policy responses, both in terms of duration and type of measure, as well as some countries' concurrent use of both trade restricting and trade facilitating measures, adds a great deal of complexity to such an analysis. ${ }^{6}$ While not the focus of this article, we view this topic as a fruitful area for further exploration, particularly looking at differential commodity effects.

\section{COVID-19, AGRICULTURAL MARKETS, AND GLOBAL TRADE TRENDS}

In this section, we provide an overview of the implications of COVID-19 on agriculture markets and trade. Specifically, we summarize the latest trade data and document the main stylized facts and trends before and during the global pandemic. Food and agricultural production and trade is generally considered an essential industry in most countries, which meant many agricultural workers, producers, wholesalers, retailers, and distributors were able to continue moving agricultural product through the supply chain (Chenarides, Manfredo and Richards 2020). However, as Yaffe-Bellany and Corkery (2020) and Lusk, Tonsor and Shulz (2020) found, the shuttering of restaurants, hotels, bars, entertainment attractions, and schools due to lockdown policies resulted in supply chain disruptions for certain agricultural products, leaving some producers with very few buyers. The COVID-19 pandemic is a complicated event because it affects both aggregate demand and supply and is dependent on the nature of the industry, the exposure of workers to illness (Luckstead et al. 2020), and the ability of supply chains to adapt to sharp changes in the way final products are consumed (i.e., food at home).

\footnotetext{
${ }^{6}$ In a separate study, Ahn and Steinbach (2021) examined the determinants and factors that prompt countries to implement NTMs during the pandemic. Their study found that for the agricultural and food sector, the effects of COVID-19 cases were more correlated with facilitating trade than restricting it. Notably, they found a lower likelihood of trade-facilitating actions with domestic COVID-19 cases whereas they found a positive association for worldwide cases.
} 


\subsection{COVID-19 trade disruption not historically large}

Disruptions to food and agricultural trade resulting from economic, natural, or trade policy induced shocks are not new. Figure 1 plots the quarterly percent change of global agricultural and non-agricultural trade from 2005Q1 through 2020Q4. Figure 2 presents monthly values of global agricultural and nonagricultural trade during the 2018-2020 period. Several sharp declines in trade standout. First, the Great Recession of 2007-2009 marked the most significant collapse in trade with global manufacturing (agricultural) trade plummeting almost 30 (20) percent (figure 1). However, the economic expansion period that followed was one of the longest on record. From 2009Q3 through 2014Q4, global agricultural and non-agricultural trade growth remained positive (the exception of 2012Q3 for non-agricultural trade). Second, beginning in 2015, world trade experienced a significant slowdown; commodity prices fell from their recent highs, the U.S. dollar appreciated, and the IMF lowered its forecast for global economic growth (see also UNCTAD, 2016). These global macro factors led to a slowdown in global trade, with U.S. and global agricultural exports falling more than 10 percent, a steeper contraction than currently observed under COVID-19 (Figure 1). Third, in 2018, a trade dispute between the United States and China and several other trading partners led to a significant escalation in applied tariffs and a resulting decline in U.S.-China agricultural and merchandise trade (Crowley 2019; Bown 2018; Bown 2019; Amiti et al. 2019; Grant et al. 2021); nevertheless, global quarterly trade growth fell only slightly below zero.

Figure 1. Changes in the growth of the value of global trade in 2020 not historically large

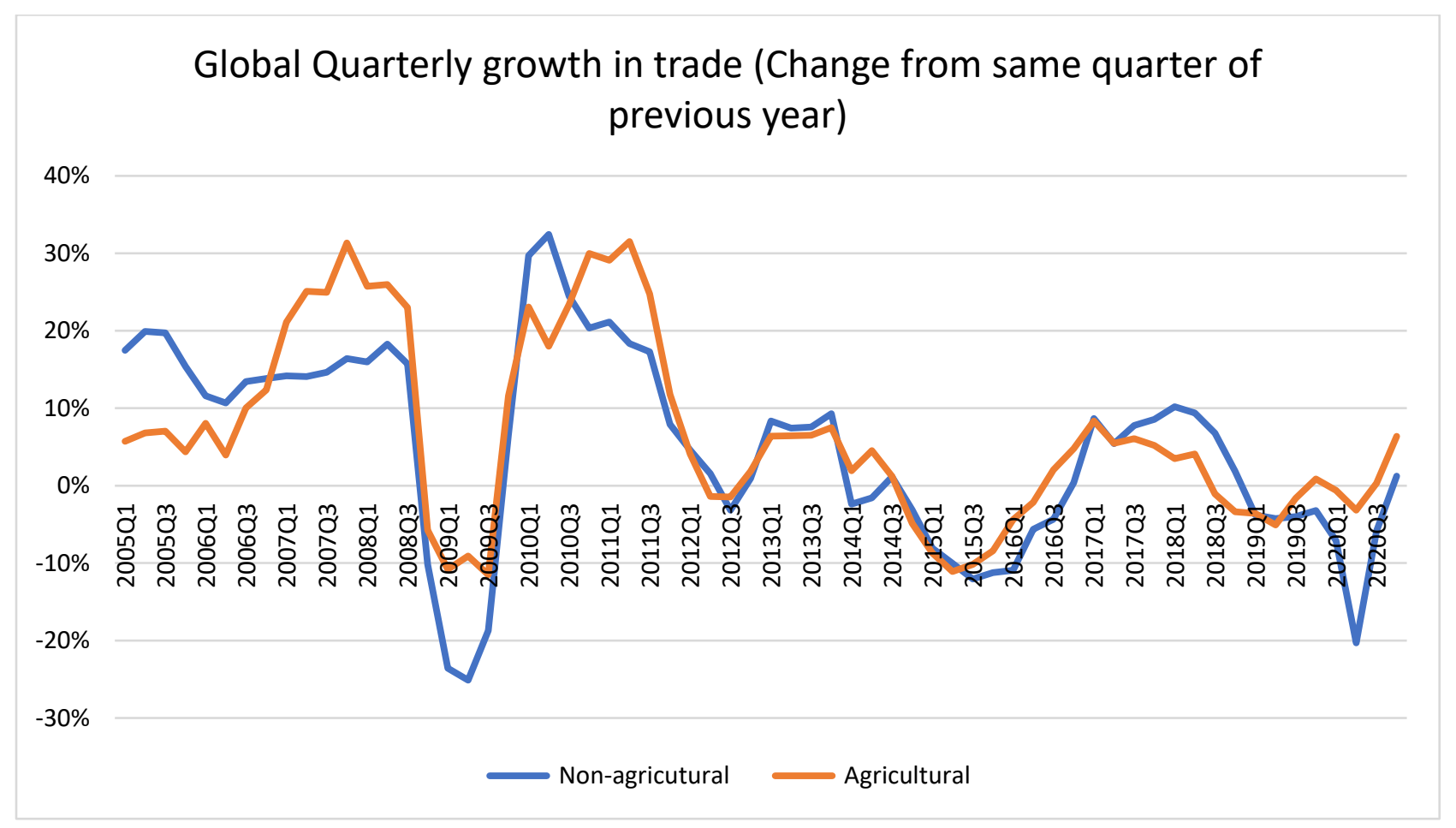

Source: Author calculations using data from Trade Data Monitor, growth is in real terms. Note: Agricultural trade includes all HS codes defined under USDA's BICO definition of Agricultural and Agricultural-related goods. Non-agricultural trade includes all other HS codes. 


\subsection{Agricultural trade relatively stable under COVID-19}

Agricultural trade under COVID-19 has been relatively stable. Global agricultural trade fell 2 percent in 2020Q2 during the initial wave of COVID-19 infections and lockdowns; however, food and agricultural trade rebounded significantly during 2020Q3 and 2020Q4 and ended the year up. On the other hand, non-agricultural trade under the COVID-19 pandemic in 2020Q2 experienced the second largest contraction in global trade since 2005. Non-agricultural trade subsequently experienced a strong recovery in Q3 and Q4, but still remained down by the end of 2020. ${ }^{7}$ The smaller impact on agricultural trade may reflect the relatively lower income elasticity of food demand, particularly for staple food items, and the structure of the agricultural global value chains which is less fragmented than manufacturing and other merchandise trade. Additionally, agricultural trade, which occurs more substantially through bulk marine shipments is likely to be less susceptible to disruption to transport restrictions in other sectors that require more human interaction (WTO, 2020b). Interestingly, compared to the Great Recession of 2007-2009 when agricultural trade fell by large amounts, trade under the pandemic has remained stable, even though in both instances global GDP fell (and the decline in GDP was larger for COVID-19).

Figure 2. Non-agricultural trade plunged in 2020; agricultural trade relatively stable

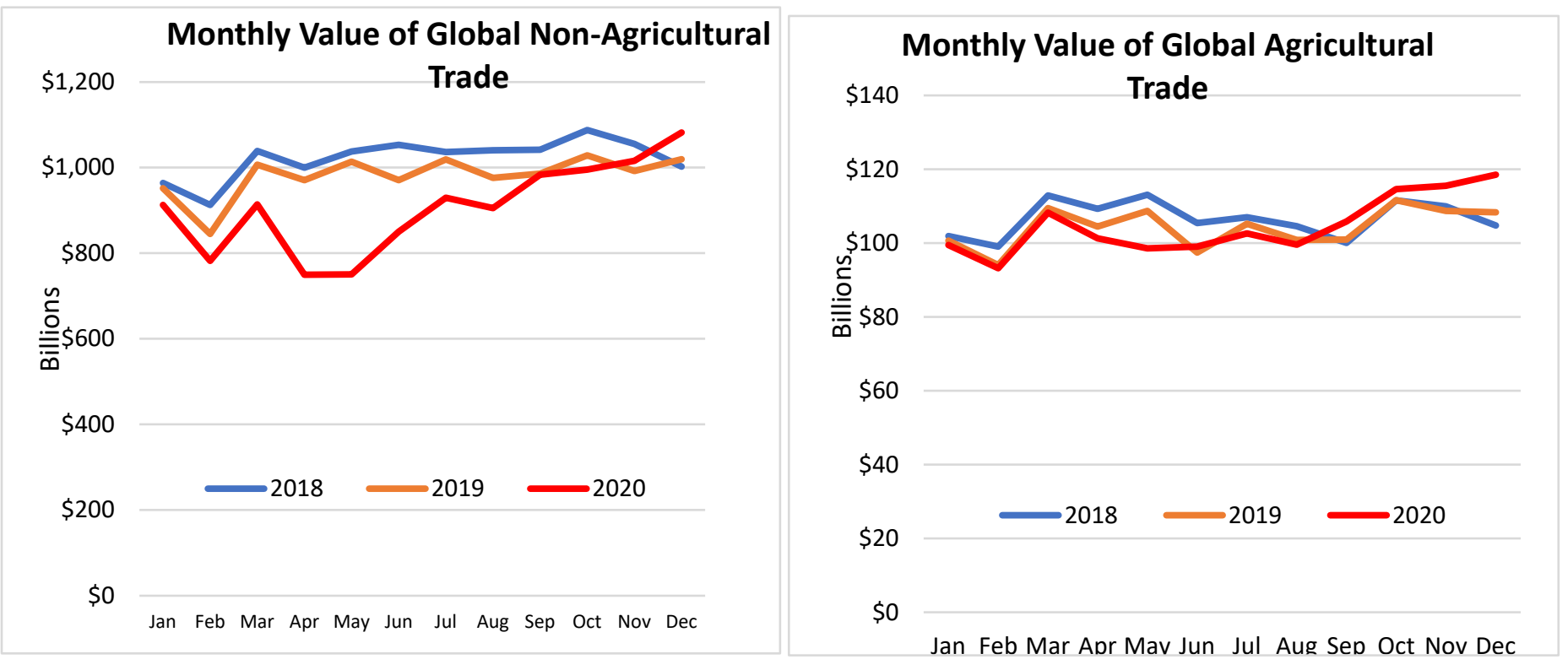

Source: Author calculations using data from Trade Data Monitor

Note: Agricultural trade includes all HS codes defined under USDA's BICO definition of Agricultural and Agricultural-related goods. Non-agricultural trade includes all other HS codes (not including trade in services). Trade values in real terms.

\subsection{Uneven changes in agricultural trade}

While overall aggregate changes in agricultural trade have been generally stable, there are differences at the product and country level. Figure 3 presents the percentage change in 2020 trade flows (in value and volume) relative to 2019 across product sector categories and trading

\footnotetext{
${ }^{7}$ Non-agriculture does not include trade in services. In 2020, global trade in services fell over 20 percent, reflecting a much more significant effect from the pandemic than merchandise trade.
} 
countries. Products used to make higher end goods such as hides and skins, cotton, rubber, and nursery are among the sectors that saw the largest contraction in trade during the COVID-19 pandemic. These sectors are more likely to have a higher income elasticity of demand and thus are relatively more susceptible to aggregate demand shocks and lockdowns. Retail sales of clothing and textiles plummeted as clothing and apparel stores closed, weaker demand for retail purchases due to stay at home orders, and lower incomes as unemployment increased or workers became furloughed. Secondly, there is a clear dichotomy between food products more likely to be consumed at home versus those being consumed away from home. For example, trade in sectors characterized by high restaurant or food away from home consumption, such as seafood, poultry, and beef products (Brinkley and Liu 2019), have declined globally. In comparison, trade in staple products such as cereal grains and protein crops, which are more likely to be consumed at home or serve as intermediate inputs for processing, has increased. Finally, the role of workers falling ill at meat packaging plants and plant closures in the United States, Brazil, and other major meat exporting countries was also expected to weigh on exports due to temporary supply disruptions (Lusk, Tonsor and Shulz 2020). However, on an annual basis figure 3 illustrates that beef, poultry and especially pork increased significantly compared to 2019 trade values.

Figure 3. Uneven changes in the value and volume of global agricultural trade

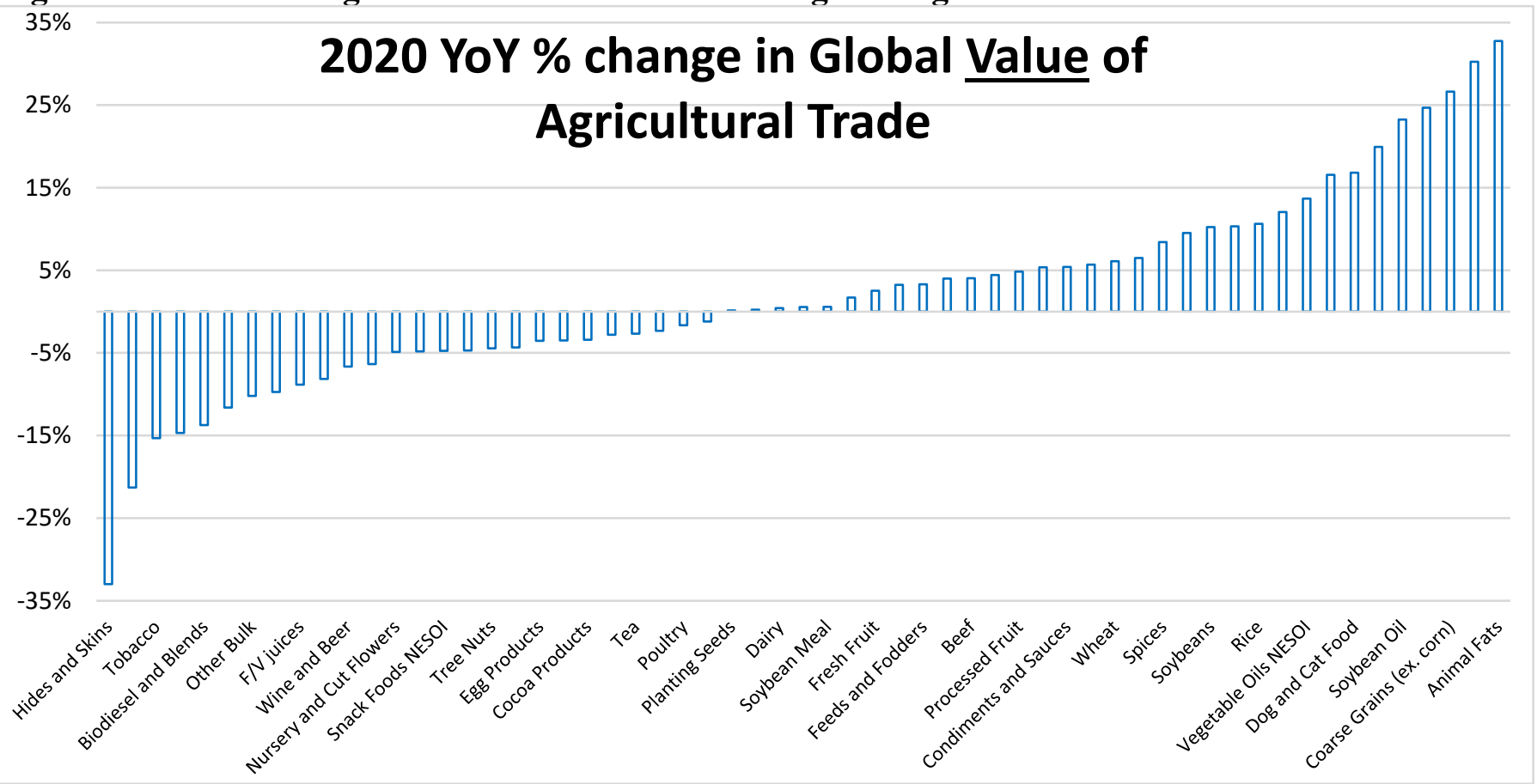




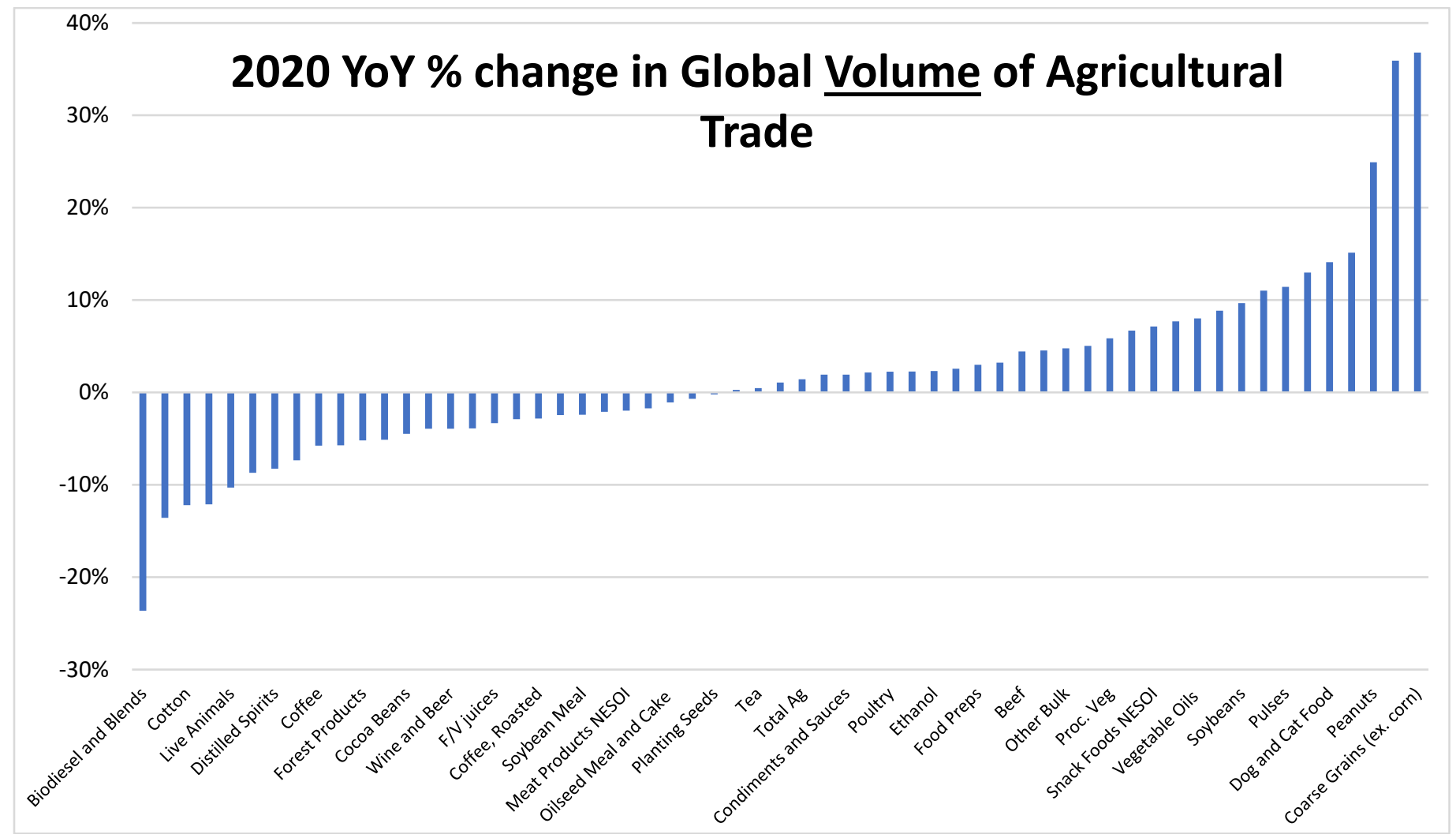

Source: Author calculations using data from Trade Data Monitor. Trade values in real terms.

\subsection{Other agricultural trade shocks occurring in 2020: Record China import demand, African Swine Fever (ASF), and policy changes}

When examining year-over-year changes in trade, it is important to recognize that there are additional trade shocks that have occurred outside COVID-19. Simple year over year changes indicate that pork and oilseeds have experienced among the highest growth in 2020, an increase driven by ASF that has ravaged herd populations in China, Asia, and other parts of the world. China - which prior to ASF consumed almost half the world's pork supply - has faced severe supply shortfalls (down more than 20 percent since 2018), and has imported record amounts of pork, raising global prices. 
Figure 4. Agricultural trade growth in 2020 dominated by strong import demand in China

\section{Change in Value of Agricultural Imports Year over Year (2020 vs 2019)}

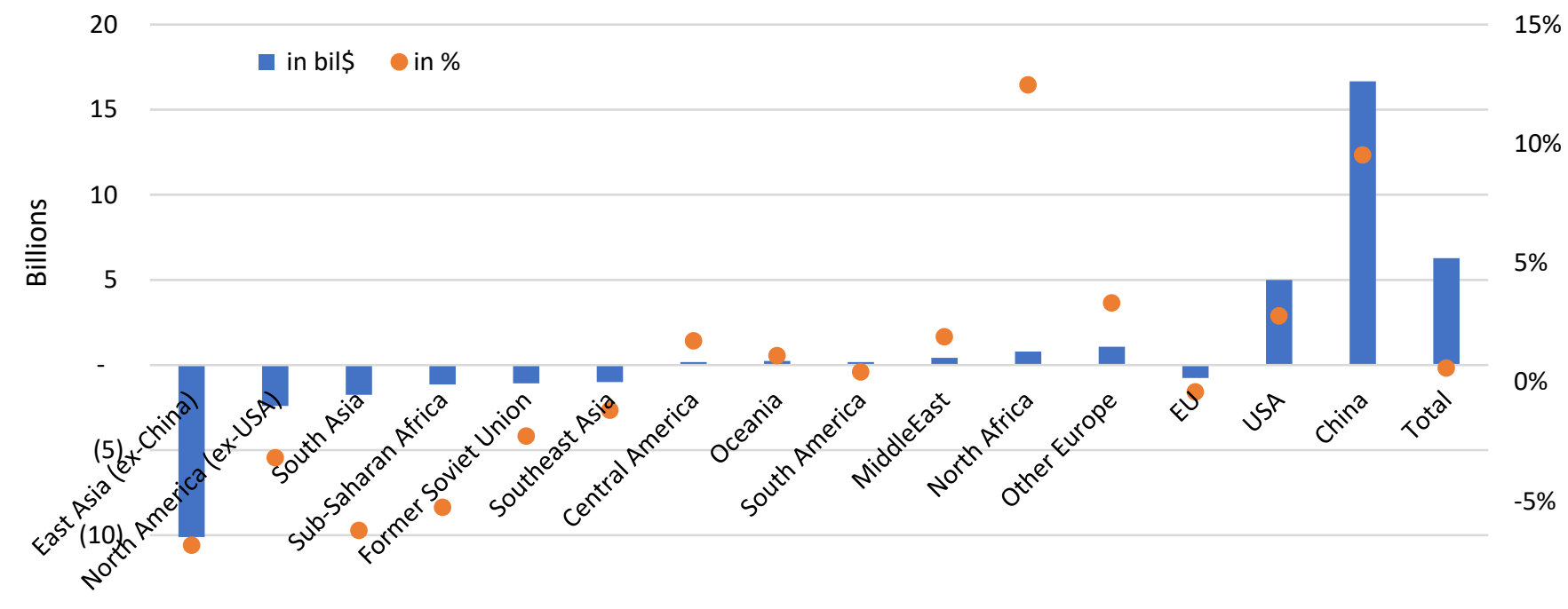

(15)

Source: Author calculations using data from Trade Data Monitor, deflated into real dollars.

As China's pig herd recovered and was further consolidated into more grain-fed operations, China's import demand for grains and oilseeds grew substantially with soybean imports expanding by an additional $\$ 4$ billion in 2020. Corn and coarse grain imports also surged on China's restocking efforts, increased demand from the larger and more grain intensive pig herd; wheat imports also increased as China has shifted some of the wheat grains to feed. The U.S.China Phase One agreement may also have supported further imports with selective waivers on retaliatory tariffs and liberalization of non-tariff measures on many key import sectors.

China, in fact, drives much of the overall observed global growth in 2020. Figure 4 shows that of the $\$ 20$ billion increase in global agricultural trade in 2020, China accounted for over 95 percent of that growth and fueled higher global commodity prices. Excluding increased China demand, the world would have experienced virtually zero agricultural trade growth in 2020. East-Asia (excluding China) and North America (excluding United States) stand out in particular in terms of weak import growth.

\section{ECONOMETRIC APPROACH AND DATA}

\subsection{Econometric model}

Descriptive analysis suggests that agricultural trade has been generally stable under COVID-19. However, most of this assessment has relied on simple year-over-year changes that ignores confounding natural (i.e., ASF) and policy-induced (i.e., U.S.-China Phase One) factors. To isolate 
the effect of COVID-19, we employ a rigorous monthly panel data econometric model of disaggregated product-line bilateral trade relationships. This approach exploits variation in country-and-month-specific indicators to estimate the (partial) direct trade effects of the pandemicinduced shock using a theoretically consistent model of bilateral trade flows at the product level as presented by Yotov et al. (2016), and Peterson et al. (2013), Baldwin and Taglioni, and Head and Mayer 2014. Following Grant et al. (2021), this approach is further extended by the use of a monthly dimension which provides a further source of within-year variation specific to many agricultural commodity exports. This framework has also been employed by Fagejlbaum et al. (2020) and Carter and Steinbach (2020) who investigated the impacts of the 2018-2019 trade war on manufacturing and agricultural product-line trade controlling for pre-trends and seasonality.

The gravity model used here is not fully structural as in Anderson and Yotov (2016) in conditional or full endowment general equilibrium (GE). By design, the GE gravity setup requires intranational trade flows (i.e., trade with self) which is nearly impossible to obtain across months within years. Thus, our results are consistent with best practices to estimate partial direct effects also advocated by Yotov et al. (2016) and Grant et al. (2021).

Denote exporting (importing) countries as $i(j)$ and products, months, and years as $k, m$, and $t$, respectively. Using monthly panel data from January 2016 through December 2020 of bilateralproduct-month relationships (ijkm), our baseline estimating equation to quantify the trade effect of COVID-19 on agricultural and non-agricultural exports is:

$$
X_{i j k m t}=\exp \left\{\mu_{i j k m}+\pi_{i t}+\varphi_{j t}+\kappa_{k t}+\xi_{m t}+\gamma_{1} \operatorname{Cov} 19_{i m t}+\gamma_{2} \operatorname{Cov} 19_{j m t}\right\}+\varepsilon_{i j k m t}
$$

where, $\exp$ denotes the exponential function, $X_{i j k m t}$ is the value of bilateral trade between exporting country $i$, importing country $j$, product group $k$, month $m(m=1,2, \ldots 12)$, and year $t$ $(t=2016,2017, \ldots 2019,2020)$. Equation (1) contains a comprehensive set of exporter-importerproduct-month specific fixed effects, ${ }^{8} \mu \mathrm{ijkm}$, designed to absorb all time-invariant product-andmonth specific bilateral trade cost or natural trading partner effects. ${ }^{9}$ Such trade cost factors include existing non-tariff measures (see Grant and Arita 2017; Ning and Grant 2019), transportation costs (i.e., distance), existing free trade agreements (i.e., U.S.-Korea, ChinaAustralia, etc.), bilateral applied tariffs, time-invariant natural, cultural and geographical factors, as well as within-year seasonality of supply and demand of product $k$. In addition to $\mu_{i j m k}$, we also include importer-year $\left(\varphi_{j t}\right)$, exporter-year $\left(\pi_{i t}\right)$, product-year $\left(\kappa_{k t}\right)$ fixed effects, and month-year $\left(\xi_{m t}\right)$ fixed effects, which are time varying, but not bilateral-specific, to control for changes in a country's overall inward or outward multilateral agri-food trade resistance (it, $j t)$ and year-toyear fluctuations in global commodity prices $(k t)$ or shifts in global agricultural trade patterns.

\footnotetext{
${ }^{8}$ In their sensitivity analysis, Grant et al (2021) included different degrees of fixed effects, with some specifications not including the full set of dummies (i.e., the exclusion of $j t, k t$, or $m t$ ). Results of their finding were generally robust to the different sets of fixed effects; however, the full set was viewed as being the most exhaustive in absorbing unobserved effects that would otherwise show up in the error term, and thus forms the basis of our estimations here. Estimates employing a smaller set of fixed effects (excluding $\pi_{i t}, \varphi_{j t}$, and/or $\xi_{k t}$ ) were also performed and found to be largely robust to the full set of fixed effects. These estimates are available upon request.

${ }^{9}$ For example, U.S.-Canada, U.S.-Mexico trade in many product lines is naturally higher than many other country-pairs in the model because of some shared border, language, cultural and institutional similarities between USMCA/NAFTA partners. If we instead tried to leverage variation between country-pairs in the model for identification, we would miss the important fact that there are pre-existing trends and trade relationships that are specific to country-pair-product and month (i.e., U.S. exports of soybeans to China peak in the post-harvest fall season, whereas Brazilian soybean exports are counter-seasonal and peak in the U.S.'s spring planting season).
} 
The direct and indirect effects of COVID-19 are captured from both the export and import side. $\operatorname{Cov19}_{\text {imt }}\left(\operatorname{Cov} 19_{\text {jmt }}\right.$ ) is an exporter-month-year (importer-month-year) specific COVID-19 variable designed to capture the influence of cases, deaths, lockdowns and mobility impacts on an exporter's (importer's) trade with all partners. COVID-19 is a complicated multifaceted shock and there is no single indicator that can reflect the entirety of its impact. Thus, we employ a battery of indicators attempting to capture different elements of its trade effect as discussed in the data section.

As suggested by Santos Silva and Tenreyro (2006), we adopt the Poisson-Pseudo-Maximum Likelihood PPML estimator because it retains the multiplicative theoretical structure of gravity type models (equation 1). It is also robust to unknown patterns of heteroskedasticity and allows the dependent variable to remain in levels (as opposed to logarithms) permitting the inclusion of zero trade flows in estimation. Zero trade flows are key in the context of assessing trade policy or pandemic-induced trade shocks at the product level, and for cases of thinner trade relationships among least developed economies for exports of certain processed food products. If the reason for zero trade is related to the COVID-19 pandemic in certain months, then omission of zero trade flows creates the classic sample selection bias leading to underestimation of trade impacts.

Finally, whereas equation (1) investigates the impact of COVID-19 on the value and volume (i.e., levels) of agricultural and non-agricultural trade, it may be the case that the pandemic's more severe disruptions occurred through supply chain logistical delays and reductions in the number of product shipments during heightened shutdown or mitigation periods to control the virus's spread. That is, the pandemic may have affected the extensive margin (number of product shipments) relatively more than the intensive margin (value or volume exported per product) of trade. U.S. census trade data track monthly export shipments at district, port, and airport locations. In total we have monthly U.S. export data for 353 ports and 52 airports for a total of 401 shipment localities.

Denoting ports as $p$, the extensive margin effect of COVID-19 is estimated as follows:

$$
N_{p m t}=\exp \left\{\mu_{p m}+\alpha_{t}+\gamma_{1} \operatorname{Cov} 19_{s m t}\right\}+\varepsilon_{p m t}
$$

where, $N_{p m t}$ is the extensive margin of trade defined as the count of the number of product shipments to the world market from port $p$, in month $m$ and year $t$. All port-level exports to the global market are included for the years 2017 and 2020 of monthly data. ${ }^{10}$ We chose 2017 as the pre-pandemic reference year when evaluating the extensive margin to mitigate any potential slow-down in some port-level shipments of agricultural products due to the U.S.-China trade dispute. During this dispute, some agricultural shipments halted, and certain products ended up in storage as the trade dispute continued. $\mu_{p m}$ and $\alpha_{t}$ are a comprehensive set of port-month and year fixed effects, respectively. In equation (1) the COVID-19 incidence rates, lockdown policy stringency and mobility indicators were defined at the country level. Because port locations can be mapped directly to U.S. States, we employ COVID-19 case and death incidence, policy stringency, and mobility indicators at the State level. Specifically, in equation (2) Cov19 $9_{\text {smt }}$ represents State-specific COVID-19 cases, deaths, Oxford Policy Stringency and Google Mobility indices across months, where $s, m$, and $t$ denote State, month and year, respectively. If

\footnotetext{
${ }^{10}$ Because of download restrictions when accessing port level shipment data, we do not include a bilateral trade dimension (i.e., port-by-destination market), and products are defined at the HS4-digit level.
} 
COVID-19 affected the extensive-product margin of trade — as measured by product throughput per port - then we would expect $\gamma_{1}$ to be negative (positive in the case of Google Mobility indicators).

\subsection{Data}

Monthly bilateral exports from January 2016 through December 2020 reported by 93 countries to 207 importing markets are retrieved from Trade Data Monitor. ${ }^{11}$ The sample includes 57 agricultural and related product groups as defined by USDA's Bulk, Intermediate and ConsumerOriented products (see appendix A and appendix B for a list of country sample and commodity grouping). Thus, an observation comprises a country pair, BICO product, month, and year. We also collect aggregate non-agricultural trade data from the same source. Given the nearly 5,000 HS6-digit product codes comprising non-agriculture we aggregate all non-agricultural products into a single sector. While this likely mask some of the pandemic's effect on individual manufacturing sectors (i.e., vehicles and parts, aircraft, electronics), it does provide a benchmark comparison from which to judge the agricultural trade effects.

U.S. port-level exports are retrieved from the U.S. Census Bureau. ${ }^{12}$ For each port we observe the monthly total value and shipping weight (i.e., volume) of exports for each HS4 product. Total export values and volumes are further broken out into the value of seaborne containerized vessel exports and the value of airborne exports to the world market. We have global exports for 428 port locations in the U.S. and a total of 501,482 port-month observations comprising the years 2017 and 2020. The extensive margin of product throughput per port is the count of the number of HS4 product exports for each month in year $t$. In terms of total export values, the largest ports in 2020 were New Orleans, Houston, Oakland, and Los Angeles with \$19, \$17.7, \$15.1, and \$12 billion of total agricultural export values, respectively. However, in terms of containerized vessels, Oakland, Los Angeles, Long Beach, and New York were the largest with 2020 agricultural exports of \$14.2, \$11.3, \$10.6, and \$7.4 billion. New York, Miami, Boston, and Detroit saw the largest airborne shipments in 2020.

COVID-19 indicators used in this study are collected from the following sources:

i. Direct outbreaks: increase in the number of coronavirus cases or deaths reported in importing country $j$ and exporting country $i$ per million people (Johns Hopkins University). These data are available at: https://github.com/CSSEGISandData/COVID-19.

ii. $\quad$ Policy Response: Oxford Policy Stringency Index in importing country $j$ and exporting country $i$. The Oxford COVID-19 Government Response Tracker (OxCGRT) systematically collects information on several different common policy responses that governments have taken to respond to the pandemic on 18 indicators such as school closures and travel restrictions. It now has data for more

\footnotetext{
11 Trade Data Monitor data are available by subscription at https://tradedatamonitor.com/. Exporter reported information was selected relative to importer reported information, since the former has arguably less data lag between transaction (time when trade sale occurred) and COVID-19 events. We also tested import reported information and found the results consistent with the export reported information.

12 Accessed at: https://usatrade.census.gov/
} 
than 180 countries. The Oxford Stringency Index ranges from 0-100. These data are available at: https://www.bsg.ox.ac.uk/research/research-projects/covid-19government-response-tracker.

iii. De facto reduction in human mobility/lockdown effect: Community Mobility indicator in importing country [deviation from pre-COVID-19 baseline] using workplace and retail people traffic are retrieved from Google Mobility data, available at: https:/www.google.com/COVID-19/mobility/.

Figure 5 presents the distribution of COVID-19 cases and death rates per million residents, the Oxford Policy Stringency Index and Google's Workplace Mobility indicator. The mean of COVID-19 cases per million residents is 1,575 with a median of 172 . Andorra, Belgium, Czech Republic, Croatia, Luxembourg, Montenegro, and Serbia experienced average monthly COVID19 cases per million residents greater than 25,000. These more extreme cases incidences occurred in October through December of 2020. Mean COVID-19 deaths per million residents is 27 with a median of 5 and a maximum of 766. Belgium, Bulgaria, Croatia, Slovenia and San Marino all experienced COVID-19 death rates per million residents above 500, which occurred in March, April, November, and December 2020. The government lockdown stringency index as reported by Oxford has a mean of 56 and a median of 58, a minimum of 1 and a maximum of 100 (100 indicates complete lockdown). Ten countries imposed lockdown stringencies that exceeded 90 on the index: Argentina, Azerbaijan, Guatemala, Honduras, India, Jordan, Philippines, Serbia, the State of Palestine, and Slovenia. Interestingly, China which was often highlighted as imposing strict lockdown measures was not on the top-10 list. China's highest Oxford Policy reading was 80 and it imposed this level of stringency for 4 out of 12 months in 2020 (i.e., a longer duration of more stringent policies to stop the viral spread). By comparison, Argentina's reading of 100 on the Oxford indicator was imposed only in April of 2020. 
Figure 5. Distribution of COVID-19 cases, deaths, policy stringency and Google Mobility, March 2020 to December 2020
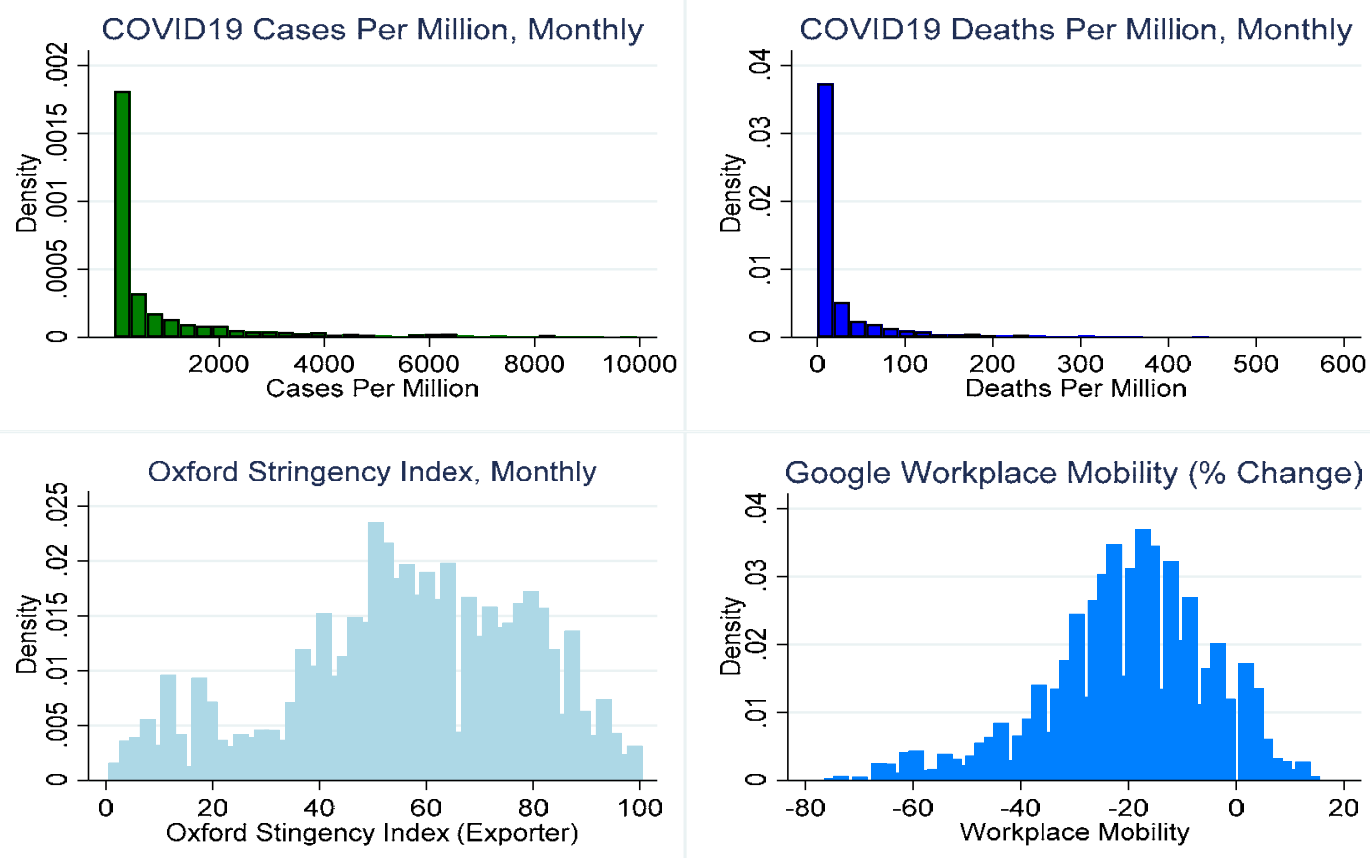

Source: Author calculations using cases and death rates data from Johns Hopkins University, Policy Stringency data from Oxford, and Workplace and Retail Mobility from Google. COVID19 cases are truncated at 10,000 monthly cases per million residents to ease horizontal axis scaling. Similarly, monthly COVID-19 deaths per million residents care truncated at 600.

Figure 6 takes a closer look at COVID-19 deaths, policy stringency and Google Mobility at the regional level: Africa, Asia, Europe, North America, and South America. Each individual color line represents a different country within the continent. For presentation purposes the figure only labels the continent. The top left panel indicates significant variation in COVID-19 rates across continents, countries, and markets; there is also substantial inter-temporal variation with different waves apparent for some countries. The Oxford Policy Stringency indices also display intertemporal variation - with strong surges during the 2nd quarter as COVID-19 became a pandemic. There is also cross-country variation as some countries, such as those in Asia, were quicker to control the pandemic. The de facto level of quarantines as measured by the Google Workplace and Retail Mobility data displays similar but distinct variation from the incidence rates and Oxford Policy indices. 
Figure 6. Deaths, Policy Stringency and Google Mobility across regions.

\section{New Deaths per Million}

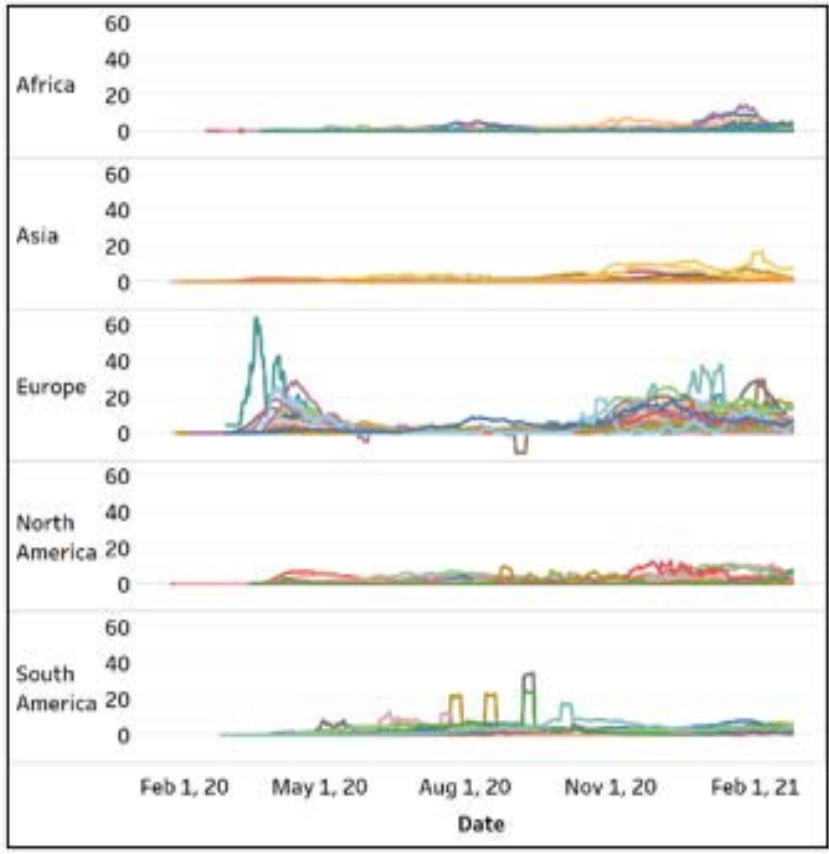

Policy Stringency

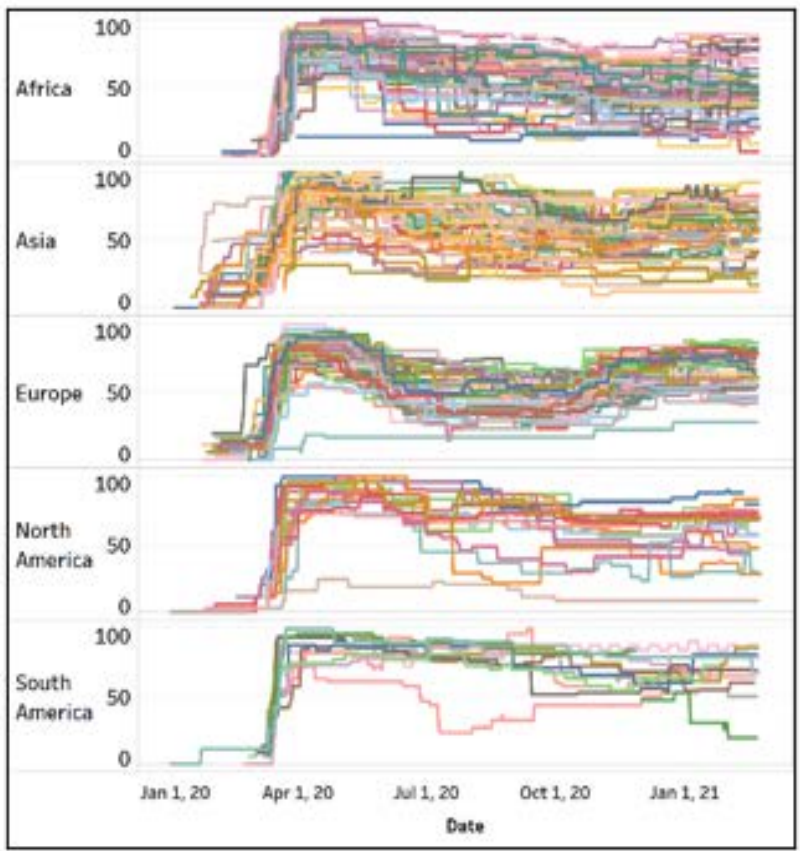

People Mobility Traffic in Workplace

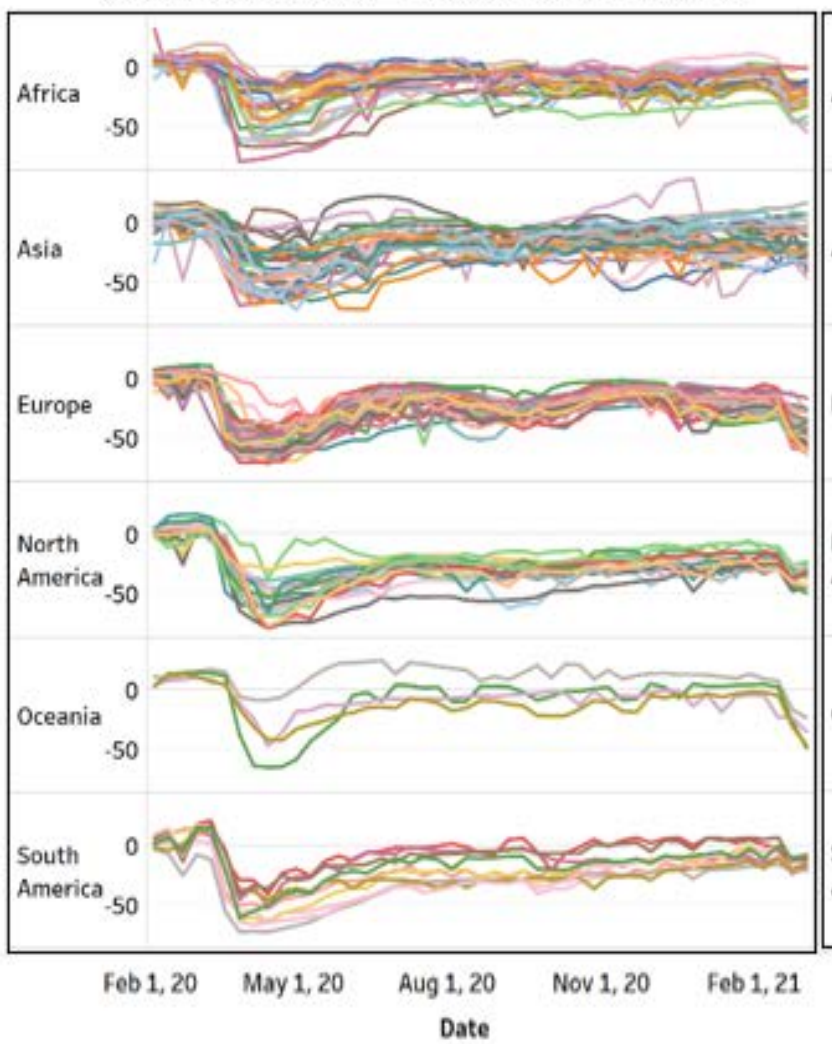

People Mobility Traffic at Retail

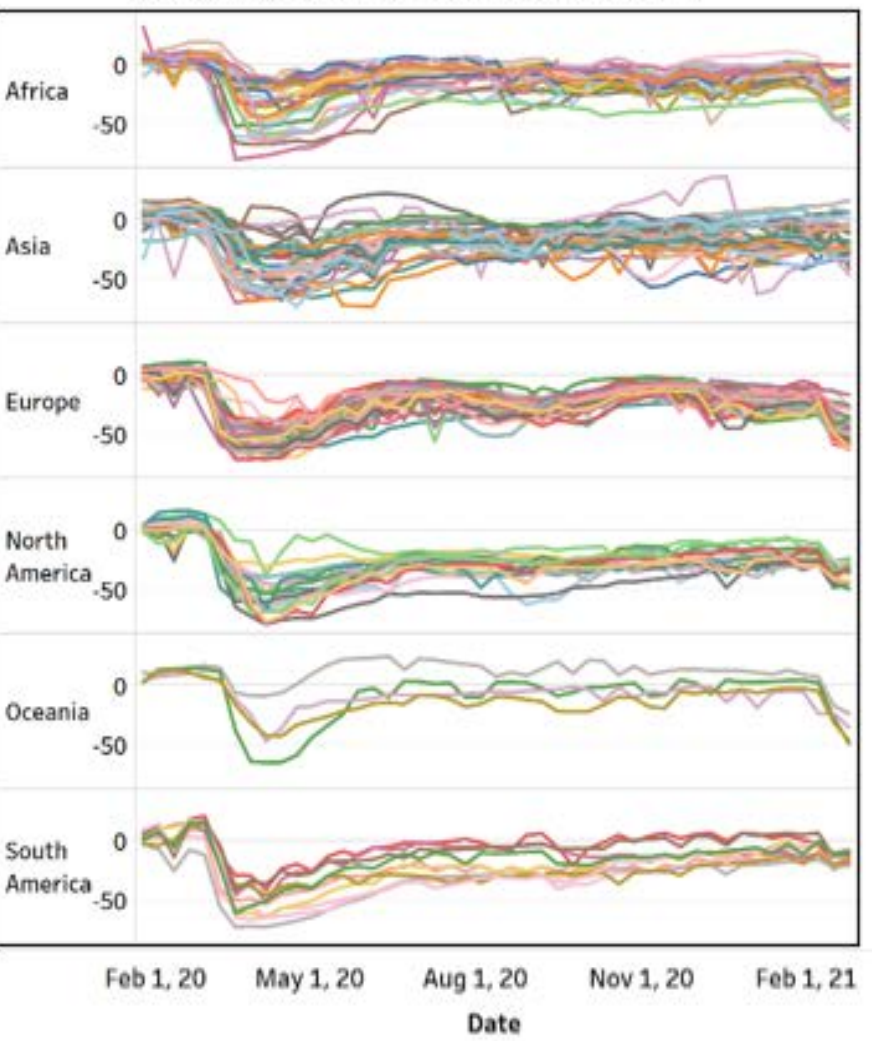

Source: Authors using death rates data from Johns Hopkins University, Policy Stringency data from Oxford, and Workplace and Retail Mobility from Google 


\section{ECONOMETRIC RESULTS}

The econometric results are organized according to different dimensions and components by which COVID-19 may be affecting international trade. Subsection one reports the overall effects on non-agricultural and agriculture. The second subsection presents the disaggregated effects on individual agricultural trade values and volumes. The third subsection examines the impacts across regions focusing in particular how trade between low income countries were affected. In the fourth subsection we address within-year timing and dynamics of the COVID-19 trade effect. Finally, in the fifth subsection we estimate the extent to which COVID-19 indicators may have impacted the extension margin of U.S. port shipments.

\subsection{Estimated sector level effects of non-agricultural vs. agricultural trade}

What is the effect of COVID-19 on global trade in 2020, holding other factors constant? Table 1 presents the aggregate sector level effects for both the value of non-agricultural and agricultural trade for different indicators of the pandemic effect. All estimations include bilateral-month (ijm), importer-year (it), exporter-year $(j t)$, and month-year $(m t)$ fixed effects. Since the estimates are performed at the overall sector level, product level fixed effects are omitted, and all standard errors are clustered by country-pair-and-month. ${ }^{13}$

Columns 1-4 report the estimated direct effect of the outbreak. The insignificant or small size of the coefficients suggests a very limited direct effect of the pandemic. For agricultural trade, a significant effect is found only on the death counts reported by the importing country. The coefficients in column 4 implies that each additional fatality per million people due to COVID19 is associated with a 0.018 -percent reduction in monthly agricultural trade. In our sample, the average number of new COVID-19 deaths reported per month, across all countries is 27 . Applying the estimated coefficient to the mean death count indicates that COVID-19 reduced agricultural trade by -0.5 percent, on average, throughout 2020 . For non-agricultural trade, the direct COVID-19 effect for death counts is significant on both the exporter and importer side; however, the average effect implied by our coefficient estimates amounts to only a 1.1-percent reduction. The effect of COVID-19 case counts is largely negligible.

The stronger effect of the pandemic is more likely to be driven by the policy response of governments attempting to curb outbreaks and the mandatory and voluntary quarantining of individuals. The next set of results supports this. Columns 5 and 6 report the estimated impact of the Oxford Policy response. For non-agricultural trade, the coefficients are negative and statistically significant on both the exporter and importer COVID-19 indicator. A one unit increase in an importer's policy restrictiveness due to COVID-19 leads to reduction of agricultural trade of 0.2 percent. In 2020, the average importing countries' policy index was elevated to 52 percent. Applying our estimated coefficient to this average indicates that government policy response to COVID-19 reduced agricultural trade flows by 10 percent, on average. Similar to the direct effect, policy restrictions on the importer side were also negative and significant for agricultural trade, but not significant on the export side. The results may suggest that the COVID-19 effect may have been more significant through import demand

\footnotetext{
${ }^{13}$ Estimates were also performed at the product level with product level fixed effects (using BICO codes). Results are provided in Appendix C. The estimates on effects of the trade value with product effects are strongly robust to the estimates at the overall agricultural sector level. A separate set of estimates were also performed in terms of volumes, which was also found to be robust to the estimates in terms of value.
} 
channels rather than export supply. In contrast, exporter's policy response to COVID-19 is found to be much stronger for non-agricultural trade, which could be attributed to the more vulnerable supply chains occurring in non-agricultural trade that are typically longer and more complex than agricultural supply chains. 
Table 1. Estimated impact of COVID-19 on the value of bilateral trade: Non-agricultural Goods vs agricultural

\begin{tabular}{|c|c|c|c|c|c|c|c|c|c|c|}
\hline VARIABLES & $\begin{array}{c}(1) \\
\text { Non-Ag } \\
\text { Goods } \\
\text { value } \\
\end{array}$ & $\begin{array}{r}(2) \\
\mathbf{A g} \\
\text { value } \\
\end{array}$ & $\begin{array}{c}(3) \\
\text { Non-Ag } \\
\text { Goods } \\
\text { value } \\
\end{array}$ & $\begin{array}{r}(4) \\
\text { Ag } \\
\text { value } \\
\end{array}$ & $\begin{array}{c}(5) \\
\text { Non-Ag } \\
\text { Goods } \\
\text { value } \\
\end{array}$ & $\begin{array}{r}\text { (6) } \\
\mathbf{A g} \\
\text { value } \\
\end{array}$ & $\begin{array}{c}(7) \\
\text { Non-Ag } \\
\text { Goods } \\
\text { value } \\
\end{array}$ & $\begin{array}{c}(8) \\
\mathbf{A g} \\
\\
\text { value } \\
\end{array}$ & $\begin{array}{c}(9) \\
\text { Non-Ag } \\
\text { Goods } \\
\text { value } \\
\end{array}$ & $\begin{array}{c}(10) \\
\text { Non-Ag } \\
\text { Goods } \\
\text { value } \\
\end{array}$ \\
\hline COVID Cases Exporter & $\begin{array}{c}-0.004 * * * \\
(0.00)\end{array}$ & $\begin{array}{l}0.002 \\
(0.00)\end{array}$ & & & & & & & & \\
\hline COVID Cases Importer & $\begin{array}{l}0.001 \\
(0.00)\end{array}$ & $\begin{array}{c}-0.003^{*} \\
(0.00)\end{array}$ & & & & & & & & \\
\hline COVID Deaths Exporter & & & $\begin{array}{c}-0.177 * * \\
(0.07)\end{array}$ & $\begin{array}{l}-0.042 \\
(0.06)\end{array}$ & & & & & $\begin{array}{l}0.120^{*} \\
(0.07)\end{array}$ & $\begin{array}{l}-0.035 \\
(0.04)\end{array}$ \\
\hline COVID Deaths Importer & & & $\begin{array}{c}-0.167 * * \\
(0.07)\end{array}$ & $\begin{array}{c}-0.248^{* * * *} \\
(0.06)\end{array}$ & & & & & $\begin{array}{l}0.041 \\
(0.08)\end{array}$ & $\begin{array}{c}-0.085^{*} \\
(0.05)\end{array}$ \\
\hline $\begin{array}{l}\text { Oxford Policy } \\
\text { Stringency Exporter }\end{array}$ & & & & & $\begin{array}{c}-0.455 * * * \\
(0.06)\end{array}$ & $\begin{array}{l}-0.044 \\
(0.03)\end{array}$ & & & $\begin{array}{l}0.002 \\
(0.05)\end{array}$ & $\begin{array}{l}0.022 \\
(0.03)\end{array}$ \\
\hline Oxford Policy & & & & & $-0.144 * * *$ & $-0.204 * * *$ & & & $0.072 *$ & 0.012 \\
\hline Stringency Importer & & & & & $(0.04)$ & $(0.05)$ & & & $(0.04)$ & $(0.03)$ \\
\hline Google Workplace & & & & & & & $0.396 * * *$ & $0.163 * * *$ & $0.443 * * *$ & $0.105^{* *}$ \\
\hline Mobility Exporter & & & & & & & $(0.05)$ & $(0.04)$ & $(0.07)$ & $(0.05)$ \\
\hline Google Retail & & & & & & & $0.249 * * *$ & $0.143 * * *$ & $0.299 * * *$ & $0.135 * * *$ \\
\hline Mobility Importer & & & & & & & $(0.03)$ & $(0.02)$ & $(0.05)$ & $(0.04)$ \\
\hline Observations & 560,288 & 494,400 & 550,098 & 485,309 & 558,093 & 492,792 & 753,584 & 644,922 & 496,991 & 440,651 \\
\hline
\end{tabular}

Notes: The Dep. variable is value of trade estimated with PPML. Includes ijm, it, jt, $m t$, fixed effects. Standard errors are in parentheses and robust to clustering on ijm. ***, and *** denote statistical significance at the 10-, 5-, and 1-percent levels, respectively. Estimated on monthly data from Jan. 2016 to Dec. 2020. Agricultural trade includes all HS codes defined under USDA's BICO definition of Agricultural and Agricultural-related goods; Non-agricultural trade includes all other HS codes. Negative effect on trade is implied by a negative sign for cases and death counts and Oxford Policy Stringency and a positive sign for Google Mobility indices. Johns Hopkin's case/death counts are rescaled per a thousand and Oxford Policy Stringency and Google Mobility indicators are rescaled to a 0\%-100\% scale. 
Columns 7 and 8 report the human mobility reduction/de-facto lockdown effect of the COVID19 using the Google Mobility indicators. Coefficients for the level of workplace mobility on the exporter side and retail mobility on the import side are positive for both non-agriculture and agriculture. ${ }^{14}$ A 1-percent decrease in the level of workplace mobility for an exporter relative to the periods prior to COVID-19, led to a 0.4-percent reduction in non-agricultural trade and a 0.16-percent reduction in agricultural trade. In our sample the average level of workplace traffic fell by 17.8 percent under the pandemic; and retail traffic by 19.1 percent. Applying these averages to the estimated coefficients implies a 6-percent reduction in the average agricultural trade flow. By comparison, the de facto lockdown effect is about twice as large for nonagricultural trade.

Columns 9 and 10 report the results estimating all components jointly. We recognize that these variables may exhibit significant multicollinearity and thus several of the individual coefficients lose significance. Similar to the previous columns we find that the estimated effect is larger for non-agricultural than agricultural trade (twice as large). Interestingly, the COVID-19 effect seems to convey more significance on the import demand side for agricultural trade, whereas for non-agricultural trade it appears to impact export supply more severely.

It is also of interest to note the differences implied by the econometric findings relative to the simple year over year changes reported in the previous section. While simple year over year changes in global agricultural trade was up +2 percent in 2020 , our estimations that leverages substantial variation in the policy response of governments and reduced mobility, either mandated or voluntary, finds statistically significant negative effects. The results suggest an approximate impact on the range of a 5-10-percent reduction in agricultural trade as predicted by the model due to COVID-19 direct and indirect factors. While 2-3 times smaller than nonagricultural trade, the results provide quantitative evidence that agricultural trade was not entirely resilient. Our findings also provide empirical support that policy restrictions and de facto lockdowns imposed by the importing countries are the main channels of trade loss.

\subsection{Which commodities were most severely impacted by the pandemic?}

In addition to some of the contrasting impacts of COVID-19 between agriculture and nonagriculture sectors, our earlier descriptive analysis also suggested noticeable differences within the agricultural sector. To understand how COVID-19 effects vary across individual product sectors, in this section we perform estimations at the commodity level as defined by USDA agricultural and agricultural-related (BICO) product groups. For these sets of estimations we estimate the joint effect of COVID-19, including direct (death counts per million), policy response (Oxford Policy Stringency), and de facto lockdown (Google Mobility) on both the importer and exporter side. ${ }^{15}$ Case counts are not included in this specification due to the weak significance of these results found within the overall agricultural sector as reported in table 1.

Appendix D shows the estimation results, across individual commodities. The findings indicate very heterogeneous COVID-19 effects. In some commodities we find very large and significant negative effects whereas others are found to carry insignificant or even positive effects. We find

\footnotetext{
14 Recall, Google Mobility indicators are in terms of deviations from a pre-pandemic benchmark, whereby reduced mobility implies a negative deviation. If reduced mobility is expected to decrease agricultural and non-agricultural trade, then we expect the sign on the mobility coefficients to be positive.

${ }^{15}$ Estimations were also performed for individual sets of COVID-19 indicators and are available upon request.
} 
that 25 percent of the commodities suffered a significant negative effect from the incidence rate (death counts) impact of the pandemic, 50-55 percent from policy restrictions, and 35-40 percent from the de facto lockdown effect. In contrast, about 10 percent of the commodities are found to have experienced a positive impact from the COVID-19, likely through demand shifting. Notably a slight majority of commodities (55-60 percent), were not found to be insignificantly affected by the pandemic.

Figure 7 attempts to stratify the impacts of the pandemic across scenarios. It employs the coefficient estimates in table 2 and applies a one standard deviation shock to each of the COVID19 effects (death counts, policy response, and de facto lockdown), and quantifies the resulting impact by commodities. The results are sorted from lowest to highest of the average impact across all indicators. Non-food agricultural commodities - hides and skins ( -15 percent), ethanol (-10 percent), cotton ( -7 percent), nursery flowers ( -6 percent), rubber $(-5$ precent $)-$ are found to have suffered the highest impacts. Certain meat products ( -5 percent) and seafood ( -5 percent), beef ( -4 percent), poultry ( -3 percent), and pork ( -2 percent) also suffer among the most severe disruptions. Distilled spirits, tea, and sugar and sweeteners - are among the other agri-food areas found to have been significantly negatively impacted.

It is of interest to note how our econometric results differ from simple year over year changes in other commodities. According to our estimates, global pork trade was reduced on average by 2 percent given a one standard deviation sized shock in COVID-19 policy restrictions and de-facto lockdown effect. This stands in strong contrast to the over 20-percent increase in global growth as shown through simple year over year changes presented in section 2.3 which was driven by ASF. Rapeseed, which experienced an 11-percent increase in global trade in 2020, largely on confounding supply side shocks, ${ }^{16}$ was found to be insignificantly impacted by COVID-19 in terms of the direct and indirect effects. Our estimation thus appears able to at least partially disentangle the COVID-19 effect for these commodities. For beef trade-which had increased in 2020 relative to 2019 _ our results found a 4-percent decline given a 1 standard deviation shock, which is consistent with the supply chain disruptions that occurred in major producing countries.

We find that for many of the grains and oilseeds and prepared and processed foods there is a relatively small or insignificant effect. The stratification of estimated impacts seems to generally align with what has been found in the income demand elasticity literature. Non-food related products are typically found to be the most sensitive to income shocks, followed by higher value meat and specialty products, then staple grains and oilseeds. Consistent with the simple year over year changes, rice - a perennial staple food item - increased 4 percent given a one standard deviation COVID-19 incidence death rate or a one standard deviation in de facto lockdown effect. Soybeans are found to have a significant positive effect from the Oxford Policy restrictions. This could be attributed to increased demand driven by China's recovering herd size and thus reflecting a possible limitation in our approach to completely isolate the COVID-19 impact; however, the effect is insignificant in terms of death counts and de facto lockdown effect.

We also estimated the impact of COVID-19 on volume of trade. By focusing on volumes, we control for commodity price changes and isolate the impacts in terms of real changes in

${ }^{16}$ For instance, EU rapeseed production suffered under droughts and disease, leading to a significant import demand increase in 2020 (Reuters, 2020). 
Figure 7. COVID-19 trade impact across commodities

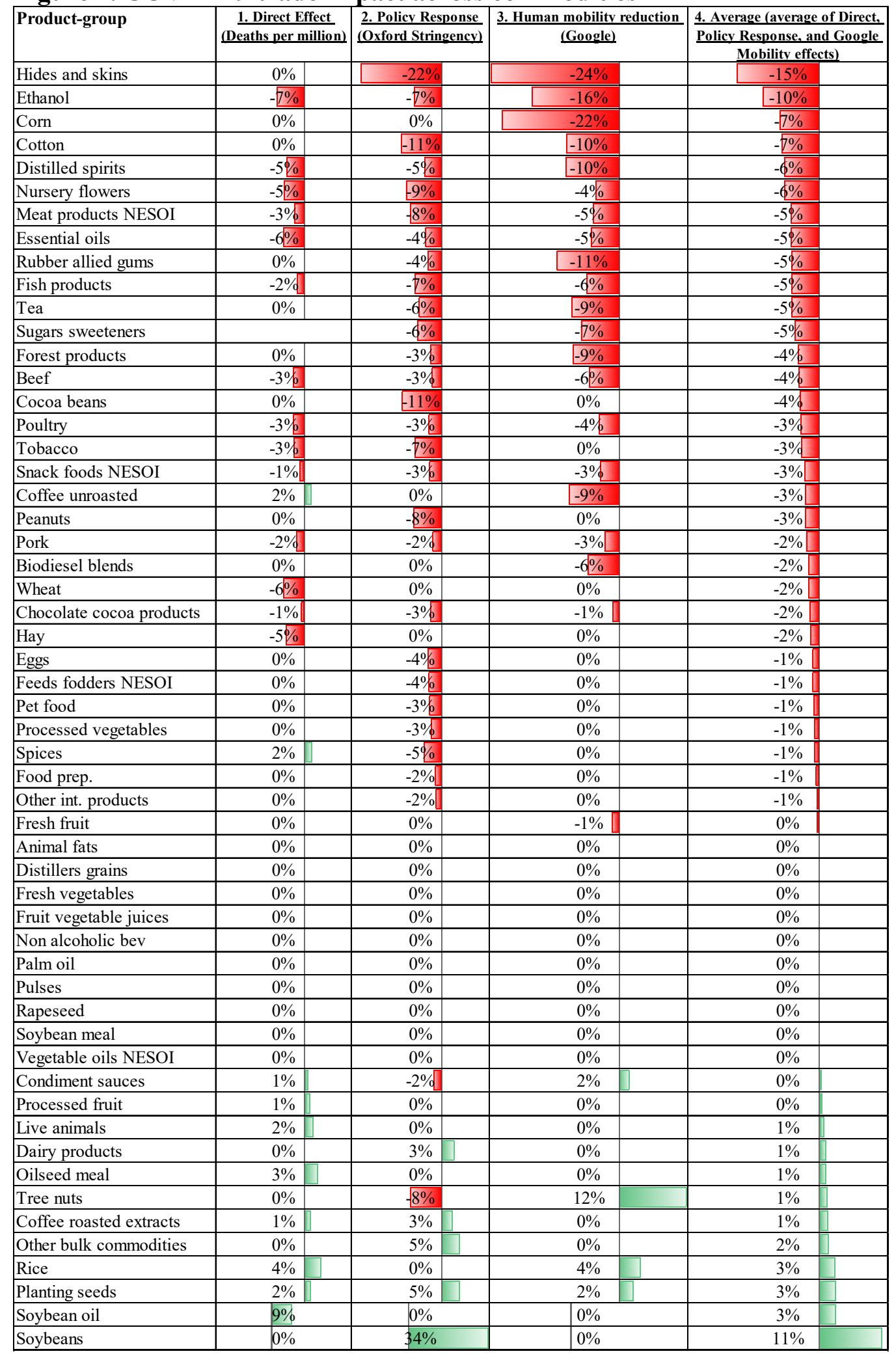

Notes: Impact applies cofficients estimated in table 2 to a one standard deviation shock of each COVID19 indicator. One standard deviation is approximately equivalent to: Death counts-50 people per million, Oxford Policy Stringency-15 percent, and Google Mobility-10 percent. Column 4 is simple average of first three columns. 
shipments. ${ }^{17}$ Results are reported in appendix E and are found to be largely consistent with the estimations performed on values and roughly similar in magnitude.

\subsection{Are low income country agricultural trade flows more vulnerable to the pandemic?}

Concerns have been raised that COVID-19 may disproportionally affect low income countries more severely compared to high income countries. On the demand side, low income countries spend a much larger share of their household budgets on food and thus their purchases are more sensitive to income changes that may be caused by COVID-19. Further, low income countries may also be more vulnerable to supply chain disruptions. Ex-ante assessments indicate significant impacts on lower income countries. For example, using the USDA Economic Research Service Food Security model, Baquedano et al. (2021) found that 160 million additional people across the world may face insecurity as result of the COVID-19 pandemic. ${ }^{18}$ Separately, the FAO estimated that an additional 118 million would become food insecure as a results of the pandemic (FAO et al. 2021). This section empirically examines whether we can detect any evidence of a disproportionate impact on low income country agricultural trade.

Table 2 performs the estimations according to selected subsamples which partition the data into income groups defined by the World Bank. Low income groups are defined as countries with a GNI per capita of less than $\$ 4 \mathrm{k}$, middle income countries $\$ 4 \mathrm{k}-\$ 12.5 \mathrm{k}$, and high income $>\$ 12.5 \mathrm{k}$. China, for example, is a middle income country. The results in table 3 report varying degrees of significance across the different specifications. Overall the differences across COVID-19 indicators and income groups tend to be mixed. The de facto level of lockdown for the importing country is generally larger for trade within low-income countries relative to trade within highincome countries. A 10-percent increase (approximately equivalent to a one standard deviation) of the de facto lockdown effect leads to a 5-percent reduction in low-income to low-income agricultural exports but only a 3-percent reduction for high-income to high income trade. However, the effects of government policy responses is mixed. Low-income to middle-income agricultural exports are significant, but low-income to low-income agricultural exports are not significant. The overall results do not seem to provide compelling evidence that low income country agricultural trade was more severly impacted by the pandemic compared to agricultural trade between high income countries. However, we caveat that given the ongoing nature of the pandemic and rising COVID-19 outbreaks occuring in 2021 for several large developing nations, further research is warranted in assessing these differences. Finally, we also note that the coefficient on deaths per importer tends to be statistically significant (and negative) across all wealth/trade spectrums, while the coefficient on deaths per exporter is only significant in two scenarios (affecting exports to high income countries).

\footnotetext{
${ }^{17}$ We note that our estimations on values does include month-time fixed effects which at least partially controls for seasonality and price effects.

${ }^{18}$ Study compares pre-pandemic forecasts from the ERS food security model to post-pandemic forecasts and finds an additional 160 million more insecure people in the post-forecast.
} 
Table 2. Impact of COVID-19 on the value of bilateral agricultural trade, by country income groups

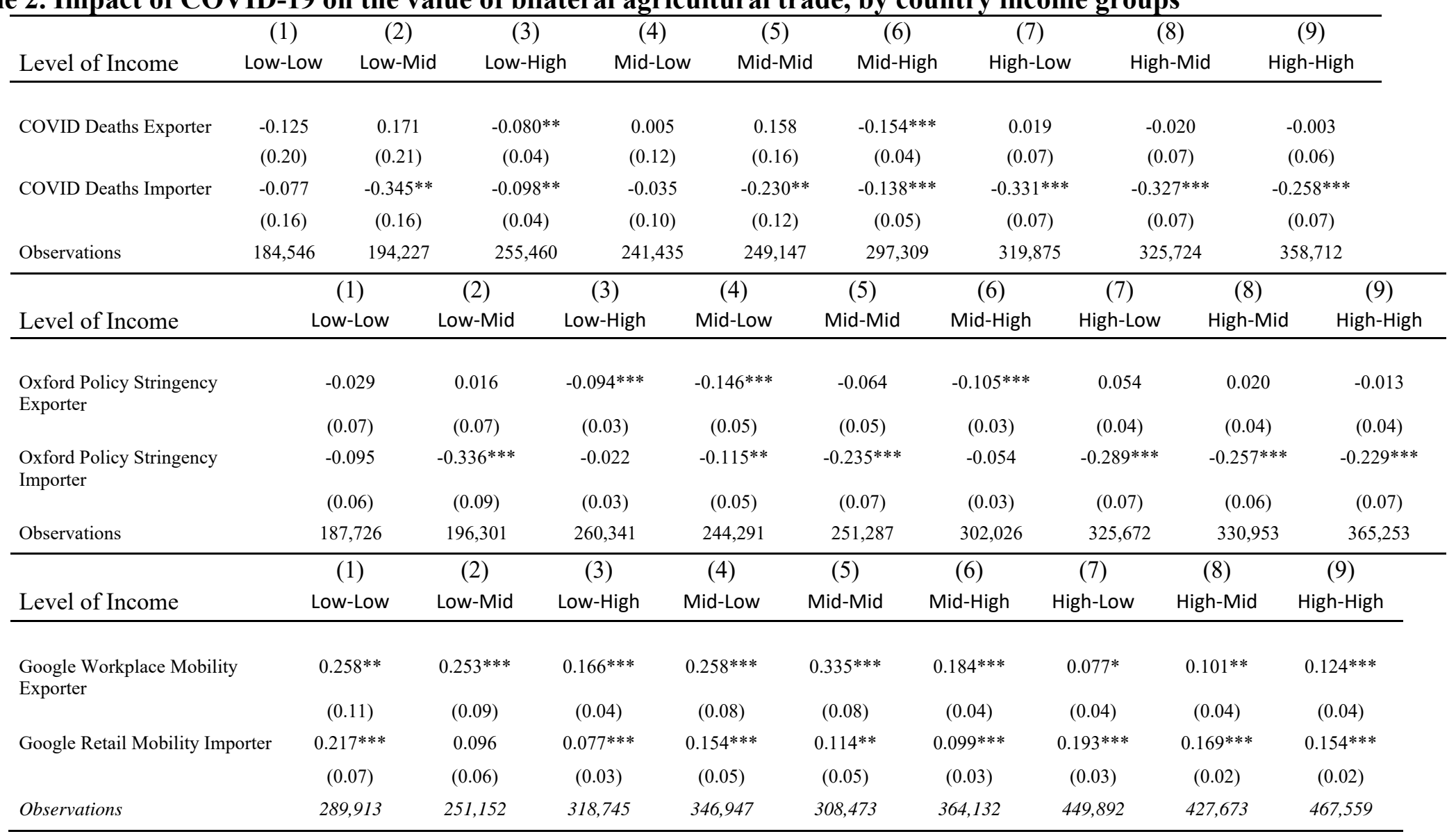

Notes: The Dep. variable is value of agricultural trade estimated with PPML. Includes ijm, it, jt, $m t$, fixed effects. Standard errors are in parentheses and robust to clustering on ijm. *,**, and *** denote statistical significance at the 10-, 5-, and 1-percent levels, respectively. Estimated on monthly data from Jan. 2016 to Dec. 2020. Agricultural trade includes all HS codes defined under USDA's BICO definition of Agricultural and Agricultural-related goods. Product groups defined by BICO codes. Income groups defined by World Bank Classification. High income countries have GNI per capita $>\$ 12.5 k$, Middle income $\$ 4-\$ 12.5 k$, and Low Income $<\$ 4 k$. (1) Low-low means low-income country exports to low-income country, (2) low-mid means low-income country exports to middle-income country, and the rest of the columns follow accordingly. Negative effect on trade is implied by a negative sign for death counts and Oxford Policy Stringency and a positive sign for Google Mobility indices. For presentation purposes of the estimations, the Johns Hopkin's case/death counts are rescaled per a thousand and Oxford Policy Stringency and Google Mobility indicators are rescaled to a 0\%-100\% scale. 


\subsection{Pandemic effects across quarters}

We also examine how COVID-19 may impact agricultural and non-agricultural trade during different periods of the pandemic. To perform this analysis, we estimate quarter-specific regressions throughout 2020 for both the non-agricultural and agricultural sector. Table 3 reports the results. Columns 1-3 presents the results using the number of deaths to explain agricultural and non-agricultural trade effects. The direct incidence rates are once again very limited and weak for both non-agricultural and agricultural trade. Columns 4-6 report the results using the Oxford Policy response. Here, the results are quite stark with a larger and more statistically significant negative COVID-19 effect under Q2 relative to Q3 and Q4. We also find that the de facto lockdown impact is most severely felt under Q2 and tends to lessen in Q3 and Q4. The joint effect indicates a similar finding.

We note that in some cases the effect is not only due to changes in the severity of COVID-19 indicators; but also attributed to an attenuation of the COVID-19 effect across time. For instance, the coefficient results for the policy restrictiveness lessens from Q2 to Q4. We observe some similar weakening for the de-facto coefficients, however to a lesser degree. The results may suggest a learning effect whereby trade and supply chains may have adjusted to both the policy restrictions and de facto lockdown factors of COVID-19 following initial disruption in Q2.

\subsection{Estimated impacts along the extensive margin of U.S. agricultural trade}

In this final section, we consider whether the pandemic has impacted the number of agricultural product shipments passing through U.S. ports. If the pandemic resulted in workers becoming ill, staying home, or mandatory shutdown of plants due to outbreaks of COVID-19, then perhaps the pandemic's effect on international trade is not necessarily through the value or volume of exports but in terms of the number of products exported as a measure of product throughput per port. U.S. port-level data tracks product shipments in aggregate and by shipment method: containerized vessel versus airlifted shipments.

Table 5 presents the results after estimation of equation (2) using the Oxford Stringency Index of the policy response of State-level governments to the pandemic (Oxford), and percentage change in Google's Workplace Mobility (Workplace), also at the State level. Overall, the results suggest that U.S. policy measures to contain the spread of the virus (Oxford) lead to a decrease in number of extensive product margin shipments per port (All Months, 2020 Table 6). Across 428 port locations, the State-level Oxford Stringency index varies widely with a mean of 52 and a standard deviation of $24 .{ }^{19}$ Thus a one (two) standard deviation increase in State governments' policy response to the de facto lockdown is representative of a 27 (92)-percent increase around the mean. The results across all months in 2020 imply a reduction of two (four) product shipments per port in 2020 on average for a one (two) standard deviation increase in the Oxford Stringency index. Similar results were obtained when evaluating the number of containerized product exports. For air shipments, however, the size of the coefficients are much more severe. Here, a one (two) standard deviation increase in State governments' Oxford Policy response is associated with three (six) fewer products transported by air per port.

\footnotetext{
${ }^{19}$ The coefficient of variation is 0.46 .
} 
Table 3. Effects of COVID-19 on the value of non-agriculture bilateral trade by quarter

\begin{tabular}{|c|c|c|c|c|c|c|c|c|c|c|c|c|}
\hline & (1) & (2) & (3) & (4) & (5) & (6) & (7) & (8) & (9) & (10) & (11) & (12) \\
\hline Quarter & Q2 & Q3 & Q4 & Q2 & Q3 & Q4 & Q2 & Q3 & Q4 & Q2 & Q3 & Q4 \\
\hline \multirow[t]{2}{*}{ COVID Deaths Exporter } & $-0.428 * * *$ & $-0.806 * * *$ & $-0.402 * * *$ & & & & & & & 0.110 & $-0.326 * *$ & 0.126 \\
\hline & $(0.13)$ & $(0.17)$ & $(0.11)$ & & & & & & & $(0.11)$ & $(0.15)$ & $(0.08)$ \\
\hline \multirow[t]{2}{*}{ COVID Deaths Importer } & $-0.377 * * *$ & $-0.408^{*}$ & 0.108 & & & & & & & $-0.204 *$ & -0.119 & $0.208^{* *}$ \\
\hline & $(0.13)$ & $(0.24)$ & $(0.09)$ & & & & & & & $(0.11)$ & $(0.16)$ & $(0.09)$ \\
\hline Oxford Policy & & & & $-0.662 * * *$ & $-0.473 * * *$ & $-0.530 * * *$ & & & & 0.003 & -0.004 & -0.001 \\
\hline Stringency Exporter & & & & $(0.07)$ & $(0.07)$ & $(0.08)$ & & & & $(0.09)$ & $(0.06)$ & $(0.07)$ \\
\hline Oxford Policy & & & & $-0.334 * * *$ & $-0.095^{* *}$ & 0.020 & & & & $-0.132 *$ & $0.076^{*}$ & 0.013 \\
\hline Stringency Importer & & & & $(0.04)$ & $(0.05)$ & $(0.05)$ & & & & $(0.07)$ & $(0.05)$ & $(0.05)$ \\
\hline Google Workplace & & & & & & & $0.458 * * *$ & $0.376 * * *$ & $0.577 * * *$ & $0.567 * * *$ & $0.367 * * *$ & $0.686^{* * *}$ \\
\hline Mobility Exporter & & & & & & & $(0.07)$ & $(0.06)$ & $(0.08)$ & $(0.12)$ & $(0.09)$ & $(0.11)$ \\
\hline Google Retail & & & & & & & $0.360 * * *$ & $0.278 * * *$ & -0.002 & $0.228 * * *$ & $0.292 * * *$ & $0.161^{* *}$ \\
\hline Mobility Importer & & & & & & & $(0.04)$ & $(0.03)$ & $(0.04)$ & $(0.07)$ & $(0.05)$ & $(0.08)$ \\
\hline Observations & 269,982 & 270,795 & 267,231 & 280,408 & 280,966 & 277,591 & 377,960 & 378,595 & 374,499 & 244,319 & 244,913 & 241,589 \\
\hline
\end{tabular}

Table 4. Effects of COVID-19 on value of agriculture bilateral trade by quarter

\begin{tabular}{|c|c|c|c|c|c|c|c|c|c|c|c|c|}
\hline Quarter & (1) & $\begin{array}{l}(2) \\
03\end{array}$ & (3) & (4) & $\begin{array}{l}(5) \\
2\end{array}$ & (6) & (7) & (8) & (9) & (10) & $\begin{array}{l}(11) \\
02\end{array}$ & (12) \\
\hline COVID Deaths Exporter & $\begin{array}{l}-0.017 \\
(0.07)\end{array}$ & $\begin{array}{l}0.001 \\
(0.13)\end{array}$ & $\begin{array}{l}0.037 \\
(0.15)\end{array}$ & & & & & & & $\begin{array}{l}0.055 \\
(0.06)\end{array}$ & $\begin{array}{l}0.118 \\
(0.11)\end{array}$ & $\begin{array}{c}-0.042 \\
(0.08)\end{array}$ \\
\hline COVID Deaths Importer & $\begin{array}{c}-0.220^{* * *} \\
(0.07)\end{array}$ & $\begin{array}{c}-0.366^{* *} \\
(0.15)\end{array}$ & $\begin{array}{l}-0.234 * \\
(0.13)\end{array}$ & & & & & & & $\begin{array}{c}-0.0836 \\
(0.06)\end{array}$ & $\begin{array}{l}-0.094 \\
(0.16)\end{array}$ & $\begin{array}{l}-0.025 \\
(0.08)\end{array}$ \\
\hline $\begin{array}{l}\text { Oxford Policy } \\
\text { Stringency Exporter }\end{array}$ & & & & $\begin{array}{c}-0.123^{* * *} \\
(0.04)\end{array}$ & $\begin{array}{l}-0.038 \\
(0.04)\end{array}$ & $\begin{array}{l}-0.036 \\
(0.06)\end{array}$ & & & & $\begin{array}{l}0.203 * * * \\
(0.06)\end{array}$ & $\begin{array}{l}0.077 \\
(0.05)\end{array}$ & $\begin{array}{l}0.000 \\
(0.06)\end{array}$ \\
\hline $\begin{array}{l}\text { Oxford Policy } \\
\text { Stringency Imnorter }\end{array}$ & & & & $\begin{array}{c}-0.241 * * * \\
(0.06)\end{array}$ & $\begin{array}{c}-0.172 * * \\
(0.07)\end{array}$ & $-0.207 * *$ & & & & $\begin{array}{c}-0.0012 \\
(0.05)\end{array}$ & $\begin{array}{l}-0.043 \\
(0.05)\end{array}$ & $\begin{array}{l}-0.005 \\
(0.05)\end{array}$ \\
\hline Google Workplace & & & & & & & $0.259 * * *$ & $0.227 * * *$ & $0.244 * * *$ & $0.430^{* * *}$ & $0.262^{* * *}$ & 0.137 \\
\hline Mobility Exporter & & & & & & & $(0.05)$ & $(0.06)$ & $(0.07)$ & $(0.09)$ & $(0.08)$ & $(0.10)$ \\
\hline Google Retail & & & & & & & $\begin{array}{c}0.121 * * * \\
(0.03)\end{array}$ & $\begin{array}{c}0.107 * * * \\
(0.03)\end{array}$ & $\begin{array}{l}0.058 \\
(0.04)\end{array}$ & $\begin{array}{l}0.091^{*} \\
(0.05)\end{array}$ & $\begin{array}{l}0.090 \\
(0.06)\end{array}$ & $\begin{array}{l}0.080 \\
(0.07)\end{array}$ \\
\hline Observations & 237,977 & 238,163 & 235,525 & 247,517 & 247,527 & 245,162 & 323,281 & 323,814 & 320,767 & 216,309 & 216,452 & 214,024 \\
\hline
\end{tabular}

Notes: The Dep. variable is value of agricultural trade estimated with PPML. Includes ijm, it, jt, mt, fixed effects. Standard errors are in parentheses and robust to clustering on ijm. *,**, and *** denote statistical significance at the 10-, 5-, and 1-percent levels, respectively. Estimated on monthly data from Jan. 2016 to Dec. 2020. Negative effect on trade is implied by a negative sign for death counts and Oxford Policy Stringency and a positive sign for Google Mobility indices. For presentation purposes of the estimations, the Johns Hopkin's case/death counts are rescaled per a thousand and Oxford Policy Stringency and Google Mobility indicators are rescaled to a $0 \%-100 \%$ scale. 
The coefficients representing Oxford's State government response to the pandemic were generally larger during the first wave (First Wave, Mar/Apr) (with the exception of containerized exports). Thereafter, the effect of State governments' response on the extensive product margin of port-level shipments declines significantly in the second and third waves of the pandemic and became largely insignificant across modes of shipment. As reported previously, this could suggest a "learning effect" as workers and port managers better understood how to manage the policy restrictions necessitated by the pandemic. One exception is the coefficient on the policy response measured by the Oxford Stringency for air shipments during the second wave of the pandemic $(-0.245)$. However, the coefficient is only significant beyond the 10-percent level (pvalue $=0.13)$.

The remaining three columns in table 5 report the results using Google's Workplace Mobility indicator at the State level matched to port locations. Here, the pandemic's mean reduction in workplace mobility is 26 percent with a standard deviation across port-month locations of 8 . The highest (absolute) reduction in workplace exceeding 60 percent occurred in Washington, DC, Massachusetts, and New Jersey port locations. The results suggest that moving from a prepandemic mobility situation to the mean (-26 percent) results in five fewer product shipment per port overall and seven fewer product shipments that are transported by air. A one standard deviation move above the mean leads to two fewer shipments per port and four fewer airtransported product shipments. In contrast to the Oxford Policy impacts, the coefficient magnitudes tend to increase in the first and second waves of the pandemic. For example, during the summer wave (Second wave (Jul/Aug)) months, a further two standard deviation reduction in workplace mobility results in seven fewer product shipments per port overall and six fewer products transported by air. This translate to an approximate 10-percent contraction in the extensive margin of port-level agricultural trade in the United States. 
Table 5. Extensive margin impacts at the U.S. port level for agricultural shipments, all months, 2017 and 2020

\begin{tabular}{|c|c|c|c|c|c|c|}
\hline & $\begin{array}{l}\text { No. Product } \\
\text { Exports }\end{array}$ & $\begin{array}{c}\text { No. } \\
\text { Container } \\
\text { Exports }\end{array}$ & $\begin{array}{l}\text { No. Air } \\
\text { Shipments }\end{array}$ & $\begin{array}{c}\text { No. } \\
\text { Product } \\
\text { Exports }\end{array}$ & $\begin{array}{c}\text { No. } \\
\text { Container } \\
\text { Exports }\end{array}$ & $\begin{array}{c}\text { No. Air } \\
\text { Shipments }\end{array}$ \\
\hline \multicolumn{7}{|l|}{ All Months, 2020} \\
\hline Oxford Policy Stringency & $\begin{array}{l}-0.079 * * * \\
{[0.010]}\end{array}$ & $\begin{array}{l}-0.070 * * * \\
{[0.019]}\end{array}$ & $\begin{array}{l}-0.117 * * * \\
{[0.017]}\end{array}$ & & & \\
\hline Google Workplace Mobility & & & & $\begin{array}{l}0.176 * * * \\
{[0.022]}\end{array}$ & $\begin{array}{l}0.126^{* *} \\
{[0.040]}\end{array}$ & $\begin{array}{l}0.253 * * * \\
{[0.034]}\end{array}$ \\
\hline $\mathrm{N}$ & 6,514 & 2,334 & 3,109 & 6,561 & 2,362 & 3,143 \\
\hline $\mathrm{R}^{2}$ & 0.99 & 0.99 & 0.99 & 0.99 & 0.99 & 0.99 \\
\hline \multicolumn{7}{|l|}{ First Wave (Mar/Apr) } \\
\hline Oxford Policy Stringency & $\begin{array}{l}-0.121 * * \\
{[0.037]}\end{array}$ & $\begin{array}{l}-0.029 \\
{[0.073]}\end{array}$ & $\begin{array}{l}-0.188 * * \\
{[0.065]}\end{array}$ & & & \\
\hline Google Workplace Mobility & & & & $\begin{array}{l}0.197 * * * \\
{[0.056]}\end{array}$ & $\begin{array}{l}0.069 \\
{[0.104]}\end{array}$ & $\begin{array}{l}0.298 * * * \\
{[0.087]}\end{array}$ \\
\hline $\mathrm{N}$ & 1,109 & 389 & 546 & 1,116 & 393 & 551 \\
\hline $\mathrm{R}^{2}$ & 0.99 & 0.99 & 0.99 & 0.99 & 0.99 & 0.99 \\
\hline \multicolumn{7}{|l|}{ Second Wave (Jul/Aug) } \\
\hline Oxford Policy Stringency & $\begin{array}{l}-0.027 \\
{[0.075]}\end{array}$ & $\begin{array}{l}0.121 \\
{[0.151]}\end{array}$ & $\begin{array}{l}-0.245 \\
{[0.162]}\end{array}$ & & & \\
\hline Google Workplace Mobility & & & & $\begin{array}{l}0.420^{*} \\
{[0.173]}\end{array}$ & $\begin{array}{l}0.156 \\
{[0.290]}\end{array}$ & $\begin{array}{l}0.394 * \\
{[0.246]}\end{array}$ \\
\hline $\mathrm{N}$ & 1,089 & 381 & 522 & 1,097 & 386 & 528 \\
\hline $\mathrm{R}^{2}$ & 0.99 & 0.99 & 0.99 & 0.99 & 0.99 & 0.99 \\
\hline \multicolumn{7}{|l|}{ Third Wave (Nov/Dec) } \\
\hline Oxford Policy Stringency & $\begin{array}{l}-0.075 \\
{[0.084]}\end{array}$ & $\begin{array}{l}0.039 \\
{[0.101]}\end{array}$ & $\begin{array}{l}-0.085 \\
{[0.148]}\end{array}$ & & & \\
\hline Google Workplace Mobility & & & & $\begin{array}{l}0.064 \\
{[0.133]}\end{array}$ & $\begin{array}{l}0.020 \\
{[0.249]}\end{array}$ & $\begin{array}{l}0.300^{*} \\
{[0.173]}\end{array}$ \\
\hline $\mathrm{N}$ & 1,072 & 396 & 508 & 1,080 & 401 & 514 \\
\hline $\mathrm{R}^{2}$ & 0.99 & 0.99 & 0.99 & 0.99 & 0.99 & 0.99 \\
\hline
\end{tabular}

Notes: the dep. var. is the number of monthly agricultural product shipments per port for all United States' port localities including airports (No. of Product Exports); the number of containerized vessel exports per port (No. of Container Exports), and the number of airlifted shipments (No. of Air Shipments). All regressions include port-month and year fixed effects. *, **, *** denote statistical significance at the 10-, 5-, and 1-percent levels, respectively. Negative effect on trade is implied by a negative sign for Oxford Policy Stringency and a positive sign for Google Mobility indices. 


\section{CONCLUSION}

This study conducted a comprehensive 1-year ex post econometric assessment of the impact of the COVID-19 pandemic on global agricultural trade. Given the multifaceted nature of the pandemic's effect on domestic markets and global trade and supply chains, summarizing the pandemic's overall impact is challenging. However, several empirical findings are apparent as it relates to this pandemic and its effects on agricultural trade.

First, holding other factors constant, our estimates suggest that COVID-19 reduced overall agricultural trade by the approximate range of 5 to 10 percent; an effect two-three times smaller than our estimated effect for non-agricultural trade. The channels by which the pandemic has impacted agricultural trade is most evident through its de facto reduction in human mobility (voluntary or mandatory based) and secondly, government policy restrictions. Direct COVID-19 case and death count incidence was found to carry very limited association and quantifiable effects on trade. For agriculture trade, the negative impacts of the pandemic estimated by our model seem to be manifested more through import demand channels as opposed to export supply shocks.

Second, sharp differences in trade impacts were observed across agriculture commodities. However, the COVID-19 trade effect permeated in many non-food items (hides and skins, ethanol, rubber, cotton), which suffered the steepest trade losses. Meat products, including seafood, and higher value agri-food products were also found to have been significantly negatively impacted. A few commodities experienced a positive impact likely due to demand shifts for staple products (e.g., rice). Nevertheless, after an extensive empirical search the majority of agricultural commodities were not found to experience a significant trade impact from the pandemic, even when investigating quarterly within-year effects associated with various 'waves' of the pandemic's more intense outbreaks and lockdown situations. We found evidence that trade flows adjusted to COVID-19 disruptions over time; however, for non-food items and some agricultural commodities, pandemic effects continued to persist through the end of 2020. Third, several international organizations including the WTO and United Nations were concerned that the pandemic may impact low income developing countries relatively more because these countries may not be as well connected to global supply chains. However, we find limited and mixed evidence that low income and least developed countries' trade flows were more vulnerable to the COVID-19 shock, although future research should investigate this effect for key commodities of export interest to low income nations.

Finally, we found evidence that the pandemic impacted the extensive margin of agricultural trade. On average, product throughput as measured by the number of products exported per port per month fell by five overall and seven fewer products by air. At the mean, this suggests an 8percent contraction in product shipments overall and 10 percent for products transported by air.

While this analysis shed light on the trade flow effects of the COVID-19 pandemic, the results should be put into perspective with the following caveats. First, the pandemic is still ongoing, and thus does not account for re-emergence of outbreaks and ongoing surges occurring in 2021 and beyond. Second, the COVID-19 coefficients may be picking up other contemporaneous factors influencing bilateral trade not explicitly considered in this analysis. For example, several countries altered their export policies including export controls on products such as medical 
supplies, personal protective equipment (PPE), and some staple agricultural products. While many of these policies were temporary in nature (i.e., lasting only a month or two), to the extent that these policies are correlated with the COVID-19 variables considered here could bias our estimates of the trade effects of de facto lockdown and immobility. Third, it would be interesting to disentangle monthly per capita income effects across countries in the sample that could be driving some of the results, particularly for higher valued non-food items. For example, many of our COVID-19 government policy and de facto lockdown results were stronger on the import demand side which could be the contemporaneous result of de facto lockdowns and declining per capita income. Although the 2020 (annual) income effect is absorbed by the importer-year fixed effect (jt), large monthly shocks to per-capita incomes are likely not well accounted for by country-time effects. ${ }^{20}$ Additional variables that more fully describe within-year seasonality and international agricultural markets and food supply chains should improve the performance of gravity-based models at the monthly level. Finally, there may be important dynamics underlying the COVID-19 indicators and the time in which trade flows are recorded in the data. That is, there may be some incongruity between the time when COVID-19 cases, deaths, government responses, and decreased mobility indicators are surging reflecting more serious phases of the pandemic and the time with which trade flow changes appear in countries' national statistics. On the other hand, while these lags may be important in the data and not fully captured in the current analysis, we tested alternative lag structures among the COVID-19 indicators with resulting estimates largely robust. ${ }^{21}$

To return to the original question posed in this article's title - How Resilient has Global Agricultural Trade Been During the First Year of the COVID-19 Coronavirus? The findings of our study suggest a qualified, "yes." Yes, this study did indeed find evidence of resilience in that the econometric results found relatively small (but still statistically significant) negative effects of the pandemic that was robust along many dimensions of analysis and slices of the data-which could be interpreted as a testament of the stability of agricultural trade, at least in aggregate. However, we would also temper any broad conclusions given the high degree of evenness of impacts found by our analysis that included evidence of severe disruptions for some sectors within agriculture. While the pandemic is still ongoing and direct and indirect effects continue to permeate across the international trading landscape, the findings summarized above offer useful empirical insights about how agricultural trade fares through a major global health crisis.

\footnotetext{
${ }^{20}$ On the other hand, for many countries, income effects may have been stabilized, in part, through fiscal stimulus measures (IMF, 2019).

${ }^{21}$ Estimates available upon request.
} 


\section{Appendix Tables and Figures}

\section{Appendix A. List of countries in dataset}

\begin{tabular}{|c|c|c|c|c|c|c|}
\hline \multicolumn{3}{|c|}{ Exporters } & \multicolumn{4}{|c|}{ Importers } \\
\hline Albania & India & Senegal & Afghanistan & Ecuador & Liberia & Saudi Arabia \\
\hline Argentina & Indonesia & Serbia & Albania & Egypt & Libya & Senegal \\
\hline Australia & Ireland & Singapore & Algeria & El Salvador & Lithuania & Serbia \\
\hline Austria & Israel & Slovakia & Andorra & Estonia & Luxembourg & Sierra Leone \\
\hline Bahrain & Italy & Slovenia & Angola & Ethiopia & Macao & Singapore \\
\hline Belarus & Japan & South Africa & Argentina & $\mathrm{Fiji}$ & Madagascar & Slovakia \\
\hline Belgium & Jordan & South Korea & Armenia & Finland & Malaysia & Slovenia \\
\hline Belize & Kazakhstan & Spain & Australia & France & Maldives & Somalia \\
\hline Bolivia & Kenya & Sri Lanka & Austria & French Polynesia & Mali & South Africa \\
\hline Bosnia & Kosovo & Sweden & Azerbaijan & Gabon & Malta & South Korea \\
\hline Botswana & Latvia & Switzerland & Bahamas & Gambia & Mauritania & Spain \\
\hline Brazil & Lithuania & Taiwan & Bahrain & Georgia & Mauritius & Sri Lanka \\
\hline Brunei & Luxembourg & Thailand & Bangladesh & Germany & Mexico & Sudan \\
\hline Bulgaria & Macao & Turkey & Belarus & Ghana & Moldova & Swaziland \\
\hline Canada & Madagascar & Ukraine & Belgium & Greece & Mongolia & Sweden \\
\hline Chile & Malaysia & United Kingdom & Benin & Guatemala & Montenegro & Switzerland \\
\hline China & Malta & United States & Bolivia & Guinea & Morocco & Syria \\
\hline Colombia & Mauritius & Uruguay & Bosnia & Haiti & Mozambique & Taiwan \\
\hline Costa Rica & Mexico & Zambia & Botswana & Honduras & Myanmar & Tajikistan \\
\hline Cote d'Ivoire & Montenegro & & Brazil & Hong Kong & Namibia & Tanzania \\
\hline Croatia & Morocco & & Brunei & Hungary & Nepal & Thailand \\
\hline Cyprus & Mozambique & & Bulgaria & Iceland & Netherlands & Togo \\
\hline Czech Republic & Myanmar & & Burkina Faso & India & New Zealand & Trinidad and Tobago \\
\hline Denmark & Namibia & & Cambodia & Indonesia & Nicaragua & Tunisia \\
\hline Ecuador & Netherlands & & Cameroon & Iran & Niger & Turkey \\
\hline Egypt & New Zealand & & Canada & Iraq & Nigeria & Turkmenistan \\
\hline El Salvador & Nicaragua & & Chile & Ireland & North Macedonia & Uganda \\
\hline Estonia & North Macedonia & & China & Israel & Norway & Ukraine \\
\hline Ethiopia & Norway & & Colombia & Italy & Oman & United Arab Emirates \\
\hline Finland & Pakistan & & Congo (DROC) & Jamaica & Pakistan & United Kingdom \\
\hline France & Panama & & Congo (ROC) & Japan & Panama & United States \\
\hline Georgia & Paraguay & & Costa Rica & Jordan & Papua New Guinea & Uruguay \\
\hline Germany & Peru & & Cote d'Ivoire & Kazakhstan & Paraguay & Uzbekistan \\
\hline Ghana & Philippines & & Croatia & Kenya & Peru & Venezuela \\
\hline Greece & Poland & & Cuba & Kuwait & Philippines & Vietnam \\
\hline Guatemala & Portugal & & Cyprus & Kyrgyzstan & Poland & Yemen \\
\hline Honduras & Qatar & & Czech Republic & Laos & Portugal & Zambia \\
\hline Hong Kong & Romania & & Denmark & Latvia & Qatar & Zimbabwe \\
\hline Hungary & Russia & & Djibouti & Lebanon & Romania & \\
\hline Iceland & Saudi Arabia & & Dominican Republic & Lesotho & Russia & \\
\hline
\end{tabular}




\begin{tabular}{|c|c|c|}
\hline $\begin{array}{l}\text { Appendix B. } \\
\text { BICO Product Category }\end{array}$ & $\begin{array}{l}\text { gricultural and } \\
\text { BICO Aggregate } \\
\text { Sector }\end{array}$ & $\begin{array}{l}\text { Agricultural-related Sectors Defined by USDA (BICO) Definition }{ }^{22} \\
\text { HS6-digit Codes Comprising BICO Sectors }\end{array}$ \\
\hline Coarse Grains & BULK & $\begin{array}{l}\text { 100200, 100290, 100300, 100390, 100400, 100490, 100700, 100790, 100820, 100829, } \\
100840,100850,100860,100890\end{array}$ \\
\hline Cocoa Beans & BULK & 180100 \\
\hline Coffee (raw/unroasted) & BULK & 090112,090111 \\
\hline Corn (not for seed) & BULK & 100590 \\
\hline Cotton & BULK & 140420,520100 \\
\hline Gums & BULK & 130190, 400110, 400121, 400122, 400129 \\
\hline Oilseeds & BULK & $\begin{array}{l}\text { 120300, 120400, 120600, 120710, 120720, 120729, 120730, 120740, 120750, } 120760 \text {, } \\
120791,120792,120799\end{array}$ \\
\hline Other Bulk & BULK & $\begin{array}{l}100810,100830,121210,121291,121292,121293,140190,140200,140210,140290, \\
140291,140299,140300,140310,140390,140490,400130,500100,500200,530110, \\
530121,530129,530130,530210,530290,530310,530390,530410,530490,530500, \\
530511,530521,530590,530591,530599\end{array}$ \\
\hline Peanuts/Groundnuts & BULK & 120210, 120220, 120241, 120242 \\
\hline Pulses & BULK & $\begin{array}{l}\text { 071310, 071320, 071331, 071332, 071333, 071334, 071335, 071339, 071340, 071350, } \\
071360,071390\end{array}$ \\
\hline Rapeseed & BULK & $120500,120510,120590$ \\
\hline Rice & BULK & $100610,100620,100630,100640$ \\
\hline Soybeans & BULK & 120190 \\
\hline Tobacco & BULK & $240110,240120,240130$ \\
\hline Wheat & $\begin{array}{l}\text { BULK } \\
\text { BULK }\end{array}$ & 100110, 100119, 100190, 100199 \\
\hline Alcohol & CONSUMER & $\begin{array}{l}220290,220291,220299,220300,220410,220421,220422,220429,220430,220510, \\
220590,220600,220810,220820,220830,220840,220850,220860,220870,220890\end{array}$ \\
\hline Beef & CONSUMER & $\begin{array}{l}\text { 020110, 020120, 020130, 020210, 020220, 020230, 020610, 020621, 020622, 020629, } \\
021020,160250\end{array}$ \\
\hline Biodiesel & CONSUMER & 382600 \\
\hline Cheese & CONSUMER & 040610, 040620, 040630, 040640, 040690 \\
\hline Cocoa products & CONSUMER & 180310, 180320, 180400, 180500, 180610, 180620, 180631, 180632, 180690 \\
\hline Coffee (roasted/processed) & CONSUMER & 090121, 090122, 090140, 090190, 210110, 210111, 210112, 210130 \\
\hline Condiments & CONSUMER & 210310, 210320, 210330, 210390, 220900 \\
\hline Dairy (excl. Cheese) & CONSUMER & $\begin{array}{l}\text { 040110, 040120, 040130, 040140, 040150, 040210, 040221, 040229, 040291, 040299, } \\
\text { 040310, 040390, 040410, 040490, 040500, 040510, 040520, 040590, 170210, 170211, } \\
170219,190110,210500,350110,350190,350220,350710,980210\end{array}$ \\
\hline Eggs & CONSUMER & $\begin{array}{l}\text { 40700, 40711, 40719, 40721, 40729, 40790, 40811, 40819, 40891, 40899, 350210, } \\
350211,350219,350290\end{array}$ \\
\hline Ethanol & CONSUMER & 220710,220720 \\
\hline Food Preparations & CONSUMER & $\begin{array}{l}\text { 190120, 190190, 190211, 190219, 190220, 190230, 190240, 190300, 190410, 190420, } \\
\text { 190430, 190490, 190590, 210410, 210420, 210690 }\end{array}$ \\
\hline Fresh Fruit & CONSUMER & $\begin{array}{l}\text { 080300, 080310, 080390, 080430, 080440, 080450, 080510, 080520, 080521, 080522, } \\
\text { 080529, 080530, 080540, 080550, 080590, 080610, 080710, 080711, 080719, 080720, } \\
\text { 080810, 080820, 080830, 080840, 080910, 080920, 080921, 080929, 080930, 080940, } \\
\text { 081010, 081020, 081030, 081040, 081050, 081060, 081070, 081090 }\end{array}$ \\
\hline Fresh Vegetables & CONSUMER & $\begin{array}{l}070110,070190,070200,070310,070320,070390,070410,070420,070490,070511, \\
070519,070521,070529,070610,070690,070700,070810,070820,070890,070910,\end{array}$ \\
\hline
\end{tabular}

22 In 2021, USDA changed its previous official definition of agriculture to follow the WTO definition of agriculture. Products including ethanol, distilled spirits, industrial alcohols, and others were added whereas other products (rubber, enzymes, and others) were removed from the USDA definition. 
Fruit/Vegetable Juice

Nursery

Other Meat

Petfood

Pork

Poultry

Processed Fruit

Processed Vegetables

Snack Food

Spices

Tea

Tree Nuts

Distiller Dried Grains

(DDGs)

Essential Oils

Fats

Fodder

Hay

Hides \& Skins

Meal
CONSUMER

CONSUMER

CONSUMER

CONSUMER

CONSUMER

CONSUMER

CONSUMER

CONSUMER

CONSUMER

CONSUMER

CONSUMER

CONSUMER

INTERMEDIATE

INTERMEDIATE

INTERMEDIATE

INTERMEDIATE

INTERMEDIATE

INTERMEDIATE

INTERMEDIATE
070920, 070930, 070940, 070951, 070952, 070959, 070960, 070970, 070990, 070991, 070992, 070993, 070999

200911, 200912, 200919, 200920, 200921, 200929, 200930, 200931, 200939, 200940, 200941, 200949, 200950, 200960, 200961, 200969, 200970, 200971, 200979, 200980, 200981, 200989, 200990

060110, 060120, 060210, 060220, 060230, 060240, 060290, 060299, 060310, 060311, 060312, 060313, 060314, 060315, 060319, 060390, 060410, 060420, 060490, 060491, 060499

20410, 20421, 20422, 20423, 20430, 20441, 20442, 20443, 20450, 20500, 20680, 20690, 20810, 20820, 20830, 20840, 20850, 20860, 20890, 21090, 21091, 21092, 21093, 21099, $41000,50400,160100,160210,160220,160290,160300$

230910

020311, 020312, 020319, 020321, 020322, 020329, 020630, 020641, 020649, 021011, 021012, 021019, 160241, 160242, 160249

020710, 020711, 020712, 020713, 020714, 020721, 020722, 020723, 020724, 020725, 020726, 020727, 020731, 020732, 020733, 020734, 020735, 020736, 020739, 020741, 020742, 020743, 020744, 020745, 020750, 020751, 020752, 020753, 020754, 020755, $020760,160231,160232,160239$

080410, 080420, 080620, 081110, 081120, 081190, 081210, 081220, 081290, 081310, 081320, 081330, 081340, 081350, 081400, 121230, 200600, 200710, 200791, 200799, 200811, 200820, 200830, 200840, 200850, 200860, 200870, 200880, 200891, 200892, 200893, 200897, 200899

071010, 071021, 071022, 071029, 071030, 071040, 071080, 071090, 071110, 071120, 071130, 071140, 071151, 071159, 071190, 071210, 071220, 071230, 071231, 071232, 071233, 071239, 071290, 071410, 071420, 071430, 071440, 071450, 071490, 121294, 121299, 200110, 200120, 200190, 200210, 200290, 200310, 200320, 200390, 200410, 200490, 200510, 200520, 200530, 200540, 200551, 200559, 200560, 200570, 200580, 200590, 200591, 200599

$170410,170490,190510,190520,190530,190531,190532,190540$

090411, 090412, 090420, 090421, 090422, 090500, 090510, 090520, 090610, 090611, 090619, 090620, 090700, 090710, 090720, 090810, 090811, 090812, 090820, 090821, 090822, 090830, 090831, 090832, 090910, 090920, 090921, 090922, 090930, 090931, 090932, 090940, 090950, 090961, 090962, 091010, 091011, 091012, 091020, 091030, 091040, 091050, 091091, 091099

090210, 090220, 090230, 090240, 090300, 210120

080110, 080111, 080112, 080119, 080120, 080121, 080122, 080130, 080131, 080132, 080211, 080212, 080221, 080222, 080231, 080232, 080240, 080241, 080242, 080250, 080251, 080252, 080260, 080261, 080262, 080270, 080280, 080290, 200819 230330

$330111,330112,330113,330114,330119,330121,330122,330123,330124,330125$, 330126, 330129, 330130, 330190, 330210

020900, 020910, 020990, 150100, 150110, 150120, 150190, 150200, 150210, 150290, $150300,150500,150510,150590,150600,151610$

$121300,121410,230210,230220,230230,230240,230250,230310,230320,230670$, 230800, 230810, 230890, 230990

121490

410110, 410120, 410121, 410122, 410129, 410130, 410140, 410150, 410190, 410210, 410221, 410229, 410310, 410320, 410330, 410390, 430110, 430120, 430130, 430140, $430150,430160,430170,430180,430190$

120890, 230500, 230610, 230620, 230630, 230640, 230641, 230649, 230650, 230660, 230690 
Other Intermediates (i.e., flours, yeasts, saps, waxes, hairs)

Palm Oil
Seed
Soy Meal
Soy Oil
Honey/Sugars
Vegetable Oil

Biodiesel
Distilled Spirits
Ethanol
Forestry
Fishery

Palm Oil

INTERMEDIATE INTERMEDIATE

INTERMEDIATE INTERMEDIATE INTERMEDIATE

INTERMEDIATE

AG RELATED

AG RELATED

AG RELATED

AG RELATED

AG RELATED
050210, 050290, 050300, 050510, 050590, 050610, 050690, 050790, 051000, 051110, 090130, 110100, 110210, 110220, 110230, 110290, 110311, 110312, 110313, 110314, 110319, 110320, 110321, 110329, 110411, 110412, 110419, 110421, 110422, 110423, $110429,110430,110510,110520,110610,110620,110630,110710,110720,110811$, $110812,110813,110814,110819,110820,110900,121010,121020,121110,121120$, $121130,121140,121150,121190,130211,130212,130213,130214,130219,130220$, $130231,130232,130239,140410,151911,151912,151919,151920,152190,180200$, 210210, 210220, 210230, 210610, 230110, 230700, 350300, 350400, 350510, 350520, 350790, 382311, 382312, 510111, 510119, 510121, 510129, 510130, 510210, 510211, 510219,510220

$151110,151190,151321,151329$

100111, 100191, 100210, 100310, 100410, 100510, 100710, 100821, 120110, 120230, $120721,120770,120910,120911,120919,120921,120922,120923,120924,120925$, 120926, 120929, 120930, 120991, 120999

120810,230400

150710, 150790

40900, 170111, 170112, 170113, 170114, 170191, 170199, 170220, 170230, 170240, $170250,170260,170290,170310,170390$

150810, 150890, 150910, 150990, 151000, 151211, 151219, 151221, 151229, 151311, 151319, 151410, 151411, 151419, 151490, 151491, 151499, 151511, 151519, 151521, $151529,151530,151540,151550,151560$,151590, 151620, 151710, 151790, 151800, $152110,291570,291615,292320$

382490,382600

2208

220710, 220712

4401-4421

All under Chapter 3, 50800, 50900, 51191, 1504, 1604, 1605, 230120 


\begin{tabular}{|c|c|c|c|c|c|c|c|c|c|c|}
\hline & (1) & (2) & (3) & (4) & (5) & (6) & (7) & (8) & (9) & (10) \\
\hline VARIABLES & Value & Volume & Value & Volume & Value & Volume & Value & Volume & Value & Volume \\
\hline \multirow[t]{2}{*}{ COVID Cases Exporter } & $0.002 * *$ & $0.006^{* *}$ & & & & & & & & \\
\hline & $(0.00)$ & $(0.00)$ & & & & & & & & \\
\hline \multirow[t]{2}{*}{ COVID Cases Importer } & $-0.003 * * *$ & $-0.005^{* *}$ & & & & & & & & \\
\hline & $(0.00)$ & $(0.00)$ & & & & & & & & \\
\hline \multirow[t]{2}{*}{ COVID Deaths Exporter } & & & -0.037 & -0.013 & & & & & -0.040 & $-0.142 * *$ \\
\hline & & & $(0.04)$ & $(0.09)$ & & & & & $(0.03)$ & $(0.07)$ \\
\hline \multirow[t]{2}{*}{ COVID Deaths Importer } & & & $-0.234 * * *$ & -0.096 & & & & & $-0.070 * * *$ & 0.030 \\
\hline & & & $(0.04)$ & $(0.07)$ & & & & & $(0.03)$ & $(0.07)$ \\
\hline \multirow{2}{*}{$\begin{array}{l}\text { Oxford Policy Stringency } \\
\text { Exporter }\end{array}$} & & & & & -0.030 & $0.136^{* * *}$ & & & 0.024 & $0.249^{* * *}$ \\
\hline & & & & & $(0.02)$ & $(0.05)$ & & & $(0.02)$ & $(0.06)$ \\
\hline \multirow{2}{*}{$\begin{array}{l}\text { Oxford Policy Stringency } \\
\text { Importer }\end{array}$} & & & & & $-0.204 * * *$ & $-0.312 * * *$ & & & 0.012 & -0.050 \\
\hline & & & & & $(0.03)$ & $(0.05)$ & & & $(0.02)$ & $(0.04)$ \\
\hline \multirow{2}{*}{$\begin{array}{l}\text { Google Workplace Mobility } \\
\text { Exporter }\end{array}$} & & & & & & & $0.147^{* * *}$ & $0.462 * * *$ & $0.091^{* * *}$ & $0.353^{* * *}$ \\
\hline & & & & & & & $(0.02)$ & $(0.07)$ & $(0.03)$ & $(0.07)$ \\
\hline \multirow{2}{*}{$\begin{array}{l}\text { Google Retail Mobility } \\
\text { Importer }\end{array}$} & & & & & & & $0.135 * * *$ & $0.054 *$ & $0.131 * * *$ & 0.063 \\
\hline & & & & & & & $(0.01)$ & $(0.03)$ & $(0.02)$ & $(0.04)$ \\
\hline Observations & $8,296,198$ & $8,053,593$ & $8,103,927$ & $7,867,905$ & $8,287,412$ & $8,044,391$ & $9,731,967$ & $9,417,002$ & $7,418,663$ & $7,202,455$ \\
\hline
\end{tabular}

Estimated with PPML. Includes ijkm, it, jt, $\mathrm{mt}$, kt, fixed effects. Standard errors are in parentheses and robust to clustering on ijkm. *,**, and ${ }^{* * *}$ denote statistical significance at the 10-, 5-, and 1-percent levels, respectively. Estimated on monthly data from Jan. 2016 to Dec. 2020. Agricultural trade includes all HS codes defined under USDA's BICO definition of Agricultural and Agricultural-related goods. Negative effect on trade is implied by a negative sign for cases and death counts and Oxford Policy Stringency and a positive sign for Google Mobility indices. For presentation purposes of the estimations, the Johns Hopkin's case/death counts are rescaled per a thousand and Oxford Policy Stringency and Google Mobility indicators are rescaled to a 0\%-100\% scale. 
Appendix D. Product level estimates on the value of bilateral agricultural trade

\begin{tabular}{|c|c|c|c|c|c|c|c|c|c|c|c|c|c|c|}
\hline & $\begin{array}{c}\text { Animal } \\
\text { Fats }\end{array}$ & Beef & $\begin{array}{c}\text { Biodiesel } \\
\text { Blends }\end{array}$ & $\begin{array}{l}\text { Chocolate } \\
\text { Cocoa } \\
\text { Products }\end{array}$ & $\begin{array}{l}\text { Coarse } \\
\text { Grains }\end{array}$ & $\begin{array}{l}\text { Cocoa } \\
\text { Beans }\end{array}$ & $\begin{array}{l}\text { Coffee } \\
\text { Roasted } \\
\text { Extracts }\end{array}$ & $\begin{array}{c}\text { Coffee } \\
\text { Unroasted }\end{array}$ & $\begin{array}{l}\text { Condiments \& } \\
\text { Sauces }\end{array}$ & Corn & Cotton & $\begin{array}{c}\text { Dairy } \\
\text { Products }\end{array}$ & $\begin{array}{l}\text { Distilled } \\
\text { Spirits }\end{array}$ & $\begin{array}{c}\text { Distillers } \\
\text { Grains }\end{array}$ \\
\hline \multicolumn{15}{|l|}{ 1. Direct Effect } \\
\hline COVID Deaths Exporter & 0.056 & -0.158 & 0.226 & $-0.192^{* *}$ & -0.215 & -0.133 & $0.296^{* *}$ & $0.345^{* *}$ & $0.192^{*}$ & -0.129 & -1.181 & -0.063 & $-0.955^{* * *}$ & 0.430 \\
\hline COVID Deaths Importer & -0.254 & $-0.611^{* * *}$ & -0.188 & -0.098 & -0.688 & 0.519 & -0.124 & 0.225 & 0.020 & 0.032 & -0.566 & 0.027 & -0.273 & -0.910 \\
\hline Observations & 76,142 & 116,020 & 25,187 & 211,421 & 78,087 & 34,732 & 167,572 & 83,748 & 184,663 & 59,471 & 38,100 & 220,479 & 166,756 & 13,665 \\
\hline \multicolumn{15}{|l|}{ 2. Policy Response } \\
\hline Oxford Policy Stringency Exporter & 0.164 & -0.118 & -0.185 & -0.011 & 0.558 & $-0.710^{*}$ & $0.184^{* *}$ & -0.143 & 0.007 & 0.467 & -0.588 & $0.222^{* * *}$ & -0.134 & 0.049 \\
\hline Oxford Policy Stringency Importer & -0.155 & $-0.177^{*}$ & -0.507 & $-0.205^{* * *}$ & $-1.449 * * *$ & 0.170 & -0.084 & -0.147 & $-0.138^{* * *}$ & -0.444 & $-0.712^{* *}$ & -0.054 & $-0.306 * *$ & 0.198 \\
\hline Observations & 78,051 & 118,557 & 25,995 & 215,637 & 80,311 & 35,853 & 171,734 & 86,240 & 188,779 & 61,164 & 39,296 & 225,336 & 170,772 & 14,124 \\
\hline \multicolumn{15}{|l|}{ 3. Human Mobility Reduction } \\
\hline Google Workplace Mobility Exporter & 0.516 & 0.164 & -0.696 & 0.147 & -0.637 & 0.211 & -0.070 & $0.931^{* * *}$ & $-0.182^{* *}$ & $2.162^{* * *}$ & -0.220 & $-0.127^{*}$ & $0.661^{* * *}$ & -1.280 \\
\hline Google Retail Mobility Importer & 0.174 & $0.550^{* * *}$ & $0.580^{* *}$ & $0.115^{* *}$ & -0.076 & -0.125 & -0.064 & -0.080 & $0.071^{*}$ & 0.273 & $0.969^{* * *}$ & 0.044 & $0.326^{* * *}$ & 0.120 \\
\hline \multirow[t]{2}{*}{ Observations } & 82,228 & 145,598 & 27,767 & 251,375 & 89,451 & 37,674 & 199,910 & 92,736 & 221,402 & 70,369 & 42,987 & 275,983 & 202,595 & 16,033 \\
\hline & Pet Food & Eggs & $\begin{array}{c}\text { Essential } \\
\text { Oils }\end{array}$ & Ethanol & $\begin{array}{l}\text { Feeds } \\
\text { Fodders }\end{array}$ & $\begin{array}{c}\text { Fish } \\
\text { Products }\end{array}$ & Food Preps & $\begin{array}{c}\text { Forest } \\
\text { Products }\end{array}$ & Fresh Fruit & $\begin{array}{c}\text { Fresh } \\
\text { Vegetables }\end{array}$ & $\begin{array}{c}\text { Fruit \& } \\
\text { Veg Juices }\end{array}$ & Hay & $\begin{array}{l}\text { Hides \& } \\
\text { Skins }\end{array}$ & $\begin{array}{c}\text { Live } \\
\text { Animals }\end{array}$ \\
\hline \multicolumn{15}{|l|}{ 1. Direct Effect } \\
\hline COVID Deaths Exporter & -0.012 & -0.179 & 0.379 & -0.498 & -0.159 & -0.126 & -0.078 & -0.052 & -0.075 & 0.269 & -0.201 & $-0.989 * *$ & -0.259 & $0.423^{*}$ \\
\hline COVID Deaths Importer & -0.061 & -0.198 & $-1.149 * *$ & $-1.490^{* * *}$ & -0.077 & $-0.382^{* * *}$ & 0.090 & -0.160 & -0.116 & -0.078 & 0.182 & -0.493 & -0.195 & -0.208 \\
\hline Observations & 105,254 & 80,181 & 184,414 & 68,702 & 173,986 & 227,709 & 303,781 & 310,180 & 159,241 & 133,451 & 169,014 & 37,533 & 62,204 & 80,024 \\
\hline \multicolumn{15}{|l|}{ 2. Policy Response } \\
\hline Oxford Policy Stringency Exporter & $-0.212^{*}$ & -0.072 & -0.153 & $-0.487^{*}$ & -0.110 & $-0.220^{* * *}$ & -0.011 & $-0.201^{* *}$ & -0.123 & -0.041 & 0.025 & 0.218 & $-0.848^{* * *}$ & 0.226 \\
\hline Oxford Policy Stringency Importer & -0.008 & $-0.239 * *$ & $-0.290^{*}$ & -0.390 & $-0.236^{* * *}$ & $-0.252^{* * *}$ & $-0.119 * *$ & -0.089 & 0.079 & 0.112 & 0.028 & -0.108 & $-0.593^{* * *}$ & 0.014 \\
\hline Observations & 107,947 & 82,153 & 188,919 & 70,566 & 178,237 & 232,835 & 309,756 & 316,452 & 162,735 & 136,375 & 172,922 & 38,703 & 64,000 & 82,126 \\
\hline \multicolumn{15}{|l|}{ 3. Human Mobility Reduction } \\
\hline Google Workplace Mobility Exporter & 0.118 & -0.042 & $0.473^{*}$ & $1.608^{* * *}$ & 0.155 & $0.317^{* * *}$ & 0.089 & $0.535^{* * *}$ & 0.116 & -0.150 & -0.084 & 0.443 & $2.385^{* * *}$ & -0.191 \\
\hline Google Retail Mobility Importer & $-0.130^{*}$ & 0.092 & $0.526^{* * *}$ & 0.152 & 0.082 & $0.283^{* * *}$ & 0.005 & $0.320^{* * *}$ & $0.134^{* *}$ & -0.035 & 0.000 & 0.113 & -0.222 & -0.173 \\
\hline Observations & 117,768 & 97,560 & 216,760 & 80,332 & 199,229 & 271,701 & 382,626 & 380,261 & 185,434 & 151,219 & 200,736 & 42,469 & 69,537 & 95,458 \\
\hline
\end{tabular}

Notes: The Dep. variable is value of agricultural trade estimated with PPML. Includes ijm, it, jt, $m t$, fixed effects. Standard errors are in parentheses and robust to clustering on ijm. *, **, and *** denote statistical significance at the 10-, 5-, and 1-percent levels, respectively.

Estimated on monthly data from Jan. 2016 to Dec. 2020. Negative effect on trade is implied by a negative sign for cases and death counts and Oxford Policy Stringency and a positive sign for Google Mobility indices. For presentation purposes of the estimations, the Johns Hopkin's case/death counts are rescaled per a thousand and Oxford Policy Stringency and Google Mobility indicators are rescaled to a 0\%-100\% scale. 
Appendix D (continued). Product level estimates on the value of bilateral agricultural trade

\begin{tabular}{|c|c|c|c|c|c|c|c|c|c|c|c|c|c|c|}
\hline & $\begin{array}{c}\text { Non } \\
\text { Alcoholic } \\
\text { Bev }\end{array}$ & $\begin{array}{l}\text { Nursery } \\
\text { flowers }\end{array}$ & $\begin{array}{l}\text { Oilseed } \\
\text { Meal }\end{array}$ & $\begin{array}{c}\text { Oilseeds } \\
\text { NESOI }\end{array}$ & $\begin{array}{l}\text { Other Bulk } \\
\text { Commodities }\end{array}$ & $\begin{array}{c}\text { Other } \\
\text { Intermediate } \\
\text { Products }\end{array}$ & Palm Oil & Peanuts & $\begin{array}{l}\text { Planting } \\
\text { Seeds }\end{array}$ & Pork & Poultry & $\begin{array}{l}\text { Processed } \\
\text { Vegetables }\end{array}$ & Pulses & Rapeseed \\
\hline \multicolumn{15}{|l|}{ 1. Direct Effect } \\
\hline COVID Deaths Exporter & 0.122 & $-0.519 * * *$ & -0.386 & -0.144 & -0.032 & 0.115 & -0.708 & -0.179 & 0.258 & -0.242 & -0.206 & -0.037 & -0.027 & -0.714 \\
\hline COVID Deaths Importer & -0.066 & $-0.566 * * *$ & $0.696 * *$ & 0.041 & -0.45 & -0.043 & -0.667 & -0.038 & $0.318^{*}$ & $-0.421^{* *}$ & $-0.620^{* * *}$ & 0.134 & 0.208 & -0.741 \\
\hline Observations & 158,127 & 141,315 & 58,379 & 121,014 & 110,573 & 287,332 & 57,463 & 41,250 & 134,570 & 102,010 & 115,777 & 215,209 & 112,846 & 22,038 \\
\hline \multicolumn{15}{|l|}{ 2. Policy Response } \\
\hline Oxford Policy Stringency Exporter & -0.13 & $-0.287^{* * *}$ & -0.106 & $-0.328^{* *}$ & $0.323^{*}$ & -0.052 & -0.439 & -0.12 & $0.312^{* * *}$ & -0.085 & $-0.231^{* *}$ & $-0.185^{* * *}$ & 0.095 & -0.55 \\
\hline Oxford Policy Stringency Importer & -0.057 & $-0.341^{* * *}$ & 0.289 & $-0.473^{* *}$ & -0.103 & $-0.102^{*}$ & -0.291 & $-0.504^{*}$ & 0.005 & $-0.161^{*}$ & -0.128 & -0.046 & 0.144 & -0.122 \\
\hline Observations & 161,849 & 144,396 & 60,090 & 124,142 & 113,770 & 293,298 & 58,884 & 42,379 & 138,217 & 104,276 & 117,952 & 219,558 & 115,679 & 22,815 \\
\hline \multicolumn{15}{|l|}{ 3. Human Mobility Reduction } \\
\hline Google Workplace Mobility Exporter & -0.098 & 0.142 & $0.651^{*}$ & $1.103^{* *}$ & 0.419 & 0.002 & $0.952^{*}$ & 0.684 & 0.154 & 0.008 & 0.129 & -0.102 & 0.056 & 0.365 \\
\hline Google Retail Mobility Importer & $0.148^{*}$ & $0.427^{* * *}$ & -0.074 & -0.087 & 0.209 & $0.079 *$ & 0.249 & 0.065 & $-0.248^{* * *}$ & $0.262^{* * *}$ & $0.371^{* * *}$ & 0.065 & -0.284 & 0.353 \\
\hline \multirow[t]{2}{*}{ Observations } & 193,836 & 159,582 & 65,416 & 136,655 & 122,999 & 348,556 & 68,484 & 44,553 & 155,879 & 127,781 & 151,049 & 254,164 & 132,515 & 25,206 \\
\hline & Rice & $\begin{array}{l}\text { Rubber } \\
\text { Allied } \\
\text { Gums }\end{array}$ & $\begin{array}{c}\text { Soybean } \\
\text { Oil }\end{array}$ & $\begin{array}{c}\text { Soybean } \\
\text { meal }\end{array}$ & Soybeans & Spices & $\begin{array}{c}\text { Sugars } \\
\text { Sweeteners }\end{array}$ & Tea & Tobacco & TreeNuts & $\begin{array}{c}\text { Vegetable } \\
\text { Oils } \\
\text { NESOI }\end{array}$ & Wheat & $\begin{array}{c}\text { Processed } \\
\text { Fruit }\end{array}$ & $\begin{array}{l}\text { Snack } \\
\text { Foods } \\
\text { NESOI }\end{array}$ \\
\hline \multicolumn{15}{|l|}{ 1. Direct Effect } \\
\hline COVID Deaths Exporter & $0.896 * * *$ & -0.594 & $1.783 * * *$ & -0.53 & 1.044 & $0.415^{*}$ & -0.176 & -0.156 & -0.012 & -0.047 & -0.038 & $-1.130^{* *}$ & $0.253^{* * *}$ & $-0.261 * * *$ \\
\hline COVID Deaths Importer & 0.41 & 0.112 & -0.99 & 0.106 & 0.103 & 0.181 & -0.202 & -0.105 & $-0.583^{*}$ & -0.164 & -0.098 & 0.352 & -0.011 & -0.009 \\
\hline Observations & 103,652 & 86,263 & 50,114 & 47,411 & 36,038 & 161,451 & 190,663 & 151,292 & 58,329 & 153,088 & 219,697 & 47,211 & 221,671 & 228,688 \\
\hline \multicolumn{15}{|l|}{ 2. Policy Response } \\
\hline Oxford Policy Stringency Exporter & 0.352 & 0.091 & 0.603 & 0.273 & $2.269^{* *}$ & $-0.322^{* *}$ & $0.260^{* *}$ & $-0.405^{* * *}$ & $-0.469^{*}$ & $-0.252^{* *}$ & 0.069 & -0.23 & -0.051 & -0.057 \\
\hline Oxford Policy Stringency Importer & 0.215 & $-0.245^{* *}$ & 0.077 & -0.315 & -0.452 & -0.025 & $-0.692^{* * *}$ & -0.086 & -0.327 & $-0.314^{* *}$ & -0.143 & -0.128 & -0.048 & $-0.217^{* * *}$ \\
\hline Observations & 105,938 & 88,931 & 51,769 & 48,867 & 37,193 & 165,348 & 194,986 & 155,269 & 59,444 & 156,798 & 224,838 & 48,599 & 226,548 & 233,145 \\
\hline \multicolumn{15}{|l|}{ 3. Human Mobility Reduction } \\
\hline Google Workplace Mobility Exporter & 0.512 & $0.859^{* * *}$ & 0.024 & -0.19 & 0.166 & $0.524^{*}$ & $0.702^{* * *}$ & $0.882^{* * *}$ & -0.595 & $-1.238^{* * *}$ & -0.055 & -0.274 & 0.058 & $0.338^{* * *}$ \\
\hline Google Retail Mobility Importer & $-0.385^{* *}$ & $0.285^{* *}$ & 0.258 & -0.099 & -0.148 & $-0.221^{*}$ & 0.129 & -0.093 & -0.039 & 0.278 & -0.012 & 0.105 & 0.034 & $0.068^{*}$ \\
\hline Observations & 123,450 & 94,948 & 59,455 & 54,474 & 39,170 & 187,933 & 226,545 & 176,436 & 64,246 & 180,071 & 260,656 & 57,168 & 258,467 & 278,045 \\
\hline
\end{tabular}

Notes: The Dep. variable is value of agricultural trade estimated with PPML. Includes ijm, it, jt, $m$ t, fixed effects. Standard errors are in parentheses and robust to clustering on ijm. *, **, and *** denote statistical significance at the 10-, 5-, and 1-percent levels, respectively. Estimated on monthly data from Jan. 2016 to Dec. 2020. Negative effect on trade is implied by a negative sign for cases and death counts and Oxford Policy Stringency and a positive sign for Google Mobility indices. For presentation purposes of the estimations, the Johns Hopkin's case/death counts are rescaled per a thousand and Oxford Policy Stringency and Google Mobility indicators are rescaled to a 0\%-100\% scale. 
Appendix E. Product level estimates on the volume of bilateral agricultural trade

\begin{tabular}{|c|c|c|c|c|c|c|c|c|c|c|c|c|c|c|}
\hline & $\begin{array}{c}\text { Animal } \\
\text { Fats }\end{array}$ & Beef & $\begin{array}{c}\text { Biodiesel } \\
\text { Blends }\end{array}$ & $\begin{array}{l}\text { Chocolate } \\
\text { Cocoa } \\
\text { Products }\end{array}$ & $\begin{array}{l}\text { Coarse } \\
\text { Grains }\end{array}$ & $\begin{array}{l}\text { Cocoa } \\
\text { Beans }\end{array}$ & $\begin{array}{l}\text { Coffee } \\
\text { Roasted } \\
\text { Extracts }\end{array}$ & $\begin{array}{c}\text { Coffee } \\
\text { Unroasted }\end{array}$ & $\begin{array}{c}\text { Condiments \& } \\
\text { Sauces }\end{array}$ & Corn & Cotton & $\begin{array}{c}\text { Dairy } \\
\text { Products }\end{array}$ & $\begin{array}{c}\text { Distilled } \\
\text { Spirits }\end{array}$ & $\begin{array}{c}\text { Distillers } \\
\text { Grains }\end{array}$ \\
\hline \multicolumn{15}{|l|}{ 1. Direct Effect } \\
\hline COVID Deaths Exporter & 0.320 & 0.055 & 0.375 & $-0.255^{* *}$ & -0.542 & 0.004 & -0.132 & $0.373^{* *}$ & $0.225^{*}$ & -0.147 & -1.152 & $-0.430^{*}$ & $-0.708 * * *$ & 0.140 \\
\hline COVID Deaths Importer & -0.260 & $-0.544^{* * *}$ & -0.299 & -0.029 & -0.528 & 0.681 & $-0.555^{* *}$ & 0.303 & 0.040 & 0.152 & -0.814 & $0.268^{*}$ & -0.178 & -0.582 \\
\hline Observations & 75,471 & 115,877 & 24,898 & 208,712 & 77,651 & 34,222 & 165,981 & 82,490 & 182,143 & 59,165 & 36,745 & 218,151 & 132,072 & 13,611 \\
\hline \multicolumn{15}{|l|}{ 2. Policy Response } \\
\hline Oxford Policy Stringency Exporter & 0.334 & -0.111 & 0.054 & 0.004 & 0.463 & -0.293 & $0.216^{* *}$ & -0.011 & $0.225^{* *}$ & 0.582 & -0.570 & -0.322 & 0.033 & 0.157 \\
\hline Oxford Policy Stringency Importer & -0.271 & $-0.280^{* * *}$ & -0.525 & $-0.226 * * *$ & $-1.444 * * *$ & -0.023 & $-0.404 *$ & -0.183 & -0.069 & -0.483 & $-0.688^{* *}$ & 0.031 & $-0.201 * *$ & 0.191 \\
\hline Observations & 77,370 & 118,409 & 25,715 & 212,847 & 79,868 & 35,303 & 170,097 & 84,935 & 186,182 & 60,847 & 37,876 & 222,946 & 134,787 & 14,065 \\
\hline \multicolumn{15}{|l|}{ 3. Human Mobility Reduction } \\
\hline Google Workplace Mobility Exporter & 0.391 & 0.223 & -0.849 & $0.231 * *$ & -0.538 & -0.075 & -0.314 & $0.831 * * *$ & $-0.475 * * *$ & $2.425 * * *$ & -0.081 & 0.219 & $0.379 * *$ & -0.695 \\
\hline Google Retail Mobility Importer & -0.026 & $0.475^{* * *}$ & $0.603^{* *}$ & 0.071 & -0.077 & 0.091 & 0.143 & -0.135 & 0.016 & 0.235 & $0.889^{* * *}$ & 0.136 & $0.256^{* * *}$ & 0.064 \\
\hline \multirow[t]{2}{*}{ Observations } & 81,508 & 145,175 & 27,423 & 247,953 & 88,974 & 36,973 & 197,752 & 91,335 & 218,223 & 69,941 & 41,103 & 272,460 & 161,182 & 15,923 \\
\hline & Pet Food & Eggs & $\begin{array}{c}\text { Essential } \\
\text { Oils }\end{array}$ & Ethanol & $\begin{array}{c}\text { Feeds } \\
\text { Fodders }\end{array}$ & $\begin{array}{c}\text { Fish } \\
\text { Products }\end{array}$ & Food Preps & $\begin{array}{c}\text { Forest } \\
\text { Products }\end{array}$ & Fresh Fruit & $\begin{array}{c}\text { Fresh } \\
\text { Vegetables }\end{array}$ & $\begin{array}{c}\text { Fruit \& } \\
\text { Veg } \\
\text { Juices } \\
\end{array}$ & Hay & $\begin{array}{c}\text { Hides \& } \\
\text { Skins }\end{array}$ & $\begin{array}{c}\text { Live } \\
\text { Animals }\end{array}$ \\
\hline \multicolumn{15}{|l|}{ 1. Direct Effect } \\
\hline COVID Deaths Exporter & 0.031 & -0.020 & 0.105 & 0.392 & -0.026 & -0.117 & $0.240^{* * *}$ & 0.006 & $0.473^{* * *}$ & 0.250 & -0.201 & $-1.229 * *$ & $0.520^{*}$ & $0.682^{* * *}$ \\
\hline COVID Deaths Importer & -0.122 & 0.136 & -0.086 & $-1.642^{* * * *}$ & -0.000 & -0.137 & 0.100 & 0.057 & -0.099 & -0.011 & 0.171 & -0.551 & -0.284 & -0.280 \\
\hline Observations & 104,508 & 75,390 & 179,518 & 53,800 & 172,313 & 223,619 & 299,053 & 293,722 & 157,168 & 131,147 & 156,415 & 37,222 & 57,417 & 65,553 \\
\hline \multicolumn{15}{|l|}{ 2. Policy Response } \\
\hline Oxford Policy Stringency Exporter & -0.083 & -0.129 & -0.168 & 0.429 & 0.161 & $-0.211^{* * *}$ & 0.081 & $-0.299 * * *$ & -0.027 & 0.020 & 0.098 & 0.336 & -0.121 & 0.054 \\
\hline Oxford Policy Stringency Importer & 0.018 & -0.211 & 0.151 & -0.088 & $-0.293 * *$ & -0.106 & $-0.143 * * *$ & -0.129 & $0.315^{* * *}$ & $0.334 * *$ & 0.051 & -0.050 & $-0.691 * * *$ & 0.079 \\
\hline Observations & 107,193 & 77,245 & 183,893 & 55,198 & 176,537 & 228,669 & 304,912 & 299,561 & 160,613 & 134,010 & 159,835 & 38,390 & 59,056 & 67,184 \\
\hline \multicolumn{15}{|l|}{ 3. Human Mobility Reduction } \\
\hline Google Workplace Mobility Exporter & 0.120 & 0.244 & 0.066 & $1.436^{* * *}$ & -0.075 & $0.308^{* * *}$ & $-0.220^{* *}$ & $0.564 * * *$ & 0.067 & $0.672 * * *$ & 0.108 & 0.562 & $0.462^{*}$ & 0.027 \\
\hline Google Retail Mobility Importer & $-0.112 * *$ & -0.151 & 0.085 & 0.119 & 0.001 & $0.262^{* * *}$ & -0.006 & $0.348^{* * *}$ & $-0.209 * *$ & $-0.433 * * *$ & -0.034 & -0.088 & $0.289^{* *}$ & -0.122 \\
\hline Observations & 116,999 & 91,136 & 210,942 & 63,273 & 196,882 & 265,097 & 376,170 & 357,380 & 182,128 & 147,855 & 184,676 & 42,101 & 63,993 & 77,345 \\
\hline
\end{tabular}

Notes: The Dep. variable is value of agricultural trade estimated with PPML. Includes ijm, it, jt, mt, fixed effects. Standard errors are in

parentheses and robust to clustering on ijm. *, **, and *** denote statistical significance at the 10-, 5-, and 1-percent levels, respectively.

Estimated on monthly data from Jan. 2016 to Dec. 2020. Negative effect on trade is implied by a negative sign for cases and death counts and

Oxford Policy Stringency and a positive sign for Google Mobility indices. For presentation purposes of the estimations, the Johns Hopkin's

case/death counts are rescaled per a thousand and Oxford Policy Stringency and Google Mobility indicators are rescaled to a 0\%-100\% scale. 
Appendix E (continued). Product level estimates on the volume of bilateral agricultural trade

\begin{tabular}{|c|c|c|c|c|c|c|c|c|c|c|c|c|c|c|}
\hline & $\begin{array}{c}\text { Non } \\
\text { Alcoholic } \\
\text { Bev }\end{array}$ & $\begin{array}{l}\text { Nursery } \\
\text { flowers }\end{array}$ & $\begin{array}{c}\text { Oilseed } \\
\text { Meal }\end{array}$ & $\begin{array}{l}\text { Oilseeds } \\
\text { NESOI }\end{array}$ & $\begin{array}{l}\text { Other Bulk } \\
\text { Commodities }\end{array}$ & $\begin{array}{c}\text { Other } \\
\text { Intermediate } \\
\text { Products }\end{array}$ & Palm Oil & Peanuts & $\begin{array}{l}\text { Planting } \\
\text { Seeds }\end{array}$ & Pork & Poultry & $\begin{array}{l}\text { Processed } \\
\text { Vegetables }\end{array}$ & Pulses & Rapeseed \\
\hline \multicolumn{15}{|l|}{ 1. Direct Effect } \\
\hline COVID Deaths Exporter & 0.216 & $-0.361^{* *}$ & -0.305 & -0.178 & -0.303 & 0.191 & -0.736 & 0.038 & 0.671 & -0.199 & -0.076 & 0.152 & 0.144 & -0.211 \\
\hline COVID Deaths Importer & -0.103 & $-0.446 * * *$ & $0.706 * *$ & -0.214 & $-0.862 * *$ & -0.070 & -0.592 & -0.003 & $-0.810^{*}$ & $-0.395^{*}$ & $-0.466 * * *$ & $0.426 * *$ & -0.245 & -0.538 \\
\hline Observations & 126,424 & 128,261 & 57,930 & 118,873 & 108,601 & 282,459 & 57,206 & 40,676 & 129,348 & 101,945 & 115,185 & 212,389 & 112,412 & 21,620 \\
\hline \multicolumn{15}{|l|}{ 2. Policy Response } \\
\hline Oxford Policy Stringency Exporter & -0.047 & $-0.246 * *$ & -0.028 & -0.079 & -0.264 & $0.232 * *$ & -0.423 & -0.178 & 0.023 & 0.022 & -0.072 & -0.154 & -0.315 & -0.401 \\
\hline Oxford Policy Stringency Importer & -0.094 & $-0.268 * *$ & 0.224 & $-0.593 * *$ & -0.089 & $-0.291 * * *$ & -0.251 & $-0.802 * * *$ & -0.080 & $-0.231 * * *$ & -0.117 & -0.043 & 0.120 & -0.146 \\
\hline Observations & 129,010 & 131,003 & 59,627 & 121,926 & 111,745 & 288,339 & 58,602 & 41,776 & 132,826 & 104,202 & 117,341 & 216,644 & 115,222 & 22,391 \\
\hline \multicolumn{15}{|l|}{ 3. Human Mobility Reduction } \\
\hline $\begin{array}{l}\text { Google Workplace Mobility } \\
\text { Exporter }\end{array}$ & -0.111 & 0.069 & 0.498 & $1.737 * * *$ & $1.624 * * *$ & -0.010 & $1.155^{* *}$ & $0.934 *$ & 0.608 & -0.115 & $0.331 * *$ & 0.111 & 0.111 & 0.096 \\
\hline Google Retail Mobility Importer & 0.080 & $0.433^{* * *}$ & -0.109 & -0.283 & 0.376 & $0.116^{*}$ & 0.153 & 0.038 & -0.289 & $0.338^{* * *}$ & $0.323^{* * *}$ & 0.083 & -0.082 & 0.168 \\
\hline \multirow[t]{2}{*}{ Observations } & 154,390 & 144,581 & 64,813 & 133,809 & 120,087 & 341,771 & 67,997 & 43,628 & 149,616 & 127,431 & 149,903 & 250,330 & 131,302 & 24,787 \\
\hline & Rice & $\begin{array}{l}\text { Rubber } \\
\text { Allied } \\
\text { Gums }\end{array}$ & $\begin{array}{c}\text { Soybean } \\
\text { Oil }\end{array}$ & $\begin{array}{c}\text { Soybean } \\
\text { meal }\end{array}$ & Soybeans & Spices & $\begin{array}{c}\text { Sugars } \\
\text { Sweeteners }\end{array}$ & Tea & Tobacco & TreeNuts & $\begin{array}{c}\text { Vegetable } \\
\text { Oils } \\
\text { NESOI }\end{array}$ & Wheat & $\begin{array}{l}\text { Processed } \\
\text { Fruit }\end{array}$ & $\begin{array}{l}\text { Snack } \\
\text { Foods } \\
\text { NESOI }\end{array}$ \\
\hline \multicolumn{15}{|l|}{ 1. Direct Effect } \\
\hline COVID Deaths Exporter & $1.788^{* * *}$ & -0.091 & $1.631 * * *$ & $-0.776^{* *}$ & 0.842 & $0.677 * * *$ & -0.148 & 0.110 & 0.193 & 0.073 & -0.109 & $-1.285^{* * *}$ & $0.312 * * *$ & 0.041 \\
\hline COVID Deaths Importer & -0.029 & 0.194 & -1.016 & 0.220 & 0.053 & 0.479 & -0.455 & 0.219 & $-0.544^{*}$ & -0.319 & 0.052 & 0.454 & -0.039 & 0.164 \\
\hline Observations & 103,151 & 84,451 & 49,791 & 47,268 & 35,888 & 158,987 & 187,684 & 148,026 & 58,344 & 151,071 & 216,926 & 46,993 & 218,665 & 226,046 \\
\hline \multicolumn{15}{|l|}{ 2. Policy Response } \\
\hline Oxford Policy Stringency Exporter & $0.670^{* *}$ & $0.436^{*}$ & 0.577 & 0.250 & $2.090 * *$ & $-0.315^{* *}$ & $0.568 * * *$ & $-0.418^{* * *}$ & -0.342 & -0.207 & 0.106 & -0.230 & -0.133 & 0.101 \\
\hline Oxford Policy Stringency Importer & 0.076 & $-0.271 * *$ & 0.187 & -0.273 & -0.445 & -0.115 & $-0.858 * * *$ & 0.016 & $-0.401 *$ & $-0.617 * * *$ & -0.119 & -0.142 & $-0.211^{* *}$ & $-0.302 * * *$ \\
\hline Observations & 105,431 & 87,062 & 51,444 & 48,726 & 37,032 & 162,815 & 191,957 & 151,949 & 59,477 & 154,729 & 222,019 & 48,378 & 223,406 & 230,382 \\
\hline \multicolumn{15}{|l|}{ 3. Human Mobility Reduction } \\
\hline $\begin{array}{l}\text { Google Workplace Mobility } \\
\text { Exporter }\end{array}$ & 0.299 & $0.730 * *$ & 0.160 & 0.021 & 0.519 & 0.090 & $1.249 * * *$ & $0.985 * * *$ & 0.180 & $-1.381 * * *$ & -0.081 & -0.333 & -0.115 & -0.096 \\
\hline Google Retail Mobility Importer & $-0.336^{* *}$ & $0.217^{*}$ & 0.187 & -0.214 & -0.200 & -0.025 & 0.105 & $-0.279 * *$ & 0.128 & 0.164 & -0.116 & 0.081 & 0.085 & 0.085 \\
\hline Observations & 122,523 & 92,988 & 58,940 & 54,243 & 38,807 & 184,788 & 221,962 & 172,140 & 62,633 & 176,547 & 256,879 & 56,823 & 254,670 & 274,546 \\
\hline
\end{tabular}

Notes: The Dep. variable is value of agricultural trade estimated with PPML. Includes ijm, it, jt, $m t$, fixed effects. Standard errors are in

parentheses and robust to clustering on ijm. *, **, and *** denote statistical significance at the 10-, 5-, and 1-percent levels, respectively.

Estimated on monthly data from Jan. 2016 to Dec. 2020. Negative effect on trade is implied by a negative sign for cases and death counts and

Oxford Policy Stringency and a positive sign for Google Mobility indices. For presentation purposes of the estimations, the Johns Hopkin's

case/death counts are rescaled per a thousand and Oxford Policy Stringency and Google Mobility indicators are rescaled to a 0\%-100\% scale. 


\section{References}

Amiti, M., Redding, S.J. Weinstein, D., 2019. The Impact of the 2018 Trade War on US Prices and Welfare. Journal of Economic Perspectives 33(4), 187-210.

https://www.aeaweb.org/articles?id=10.1257/jep.33.4.187

Anderson, J.E. and Yotov, Y.V., 2016. Terms of Trade and Global Efficiency Effects of Free Trade Agreements, 1990-2002. Journal of International Economics, 99, 279-298.

https://www.sciencedirect.com/science/article/pii/S0022199615001531

Arita, S., Grant, J., Sydow, S., 2021. Has COVID-19 Caused a Great Trade Collapse? An Initial Ex Post Assessment. Choices. Quarter 3. https://www.choicesmagazine.org/choicesmagazine/theme-articles/agricultural-market-response-to-covid-19/has-covid-19-caused-a-greattrade-collapse-an-initial-ex-post-assessment

Baldwin, R. and Taglioni, D., 2006. Gravity for Dummies and Dummies for Gravity Equations (No. w12516). National bureau of economic research.

https://www.nber.org/papers/w12516.

Baquedano, F., Zereyesus, Y., Christensen, C., Valdes, C., 2021. International Food Security Assessment, 2020-2030: COVID-19 Update and Impacts on Food Insecurity. USDA Economic Research Service: COVID-19 Working Paper \#AP-087. https://www.ers.usda.gov/webdocs/publications/100276/ap-087.pdf?v=3889.4

Beckman, J., Countryman, A., 2021. The Importance of Agriculture in the Economy: Impacts from COVID-19, American Journal of Agricultural Economics 103(5), 1595-1611.

https://doi.org/10.1111/ajae.12212

Bown, C. P. 2018. Trump's Trade War Timeline: An Up-to-Date Guide. Trade and Investment Policy Watch (blog), Peterson Institute for International Economics (April 19, 2018).

https://www.piie.com/blogs/tradeinvestment-policy-watch/trump-trade-war-china-date-guide

Bown, C. P. 2019. US-China Trade War: The Guns of August. Trade and Investment Policy Watch (blog), Peterson Institute for International Economics (September 20). https://www.piie.com/blogs/trade-andinvestment-policy-watch/us-china-trade-war-guns-august.

Brahmbhatt, M., Datta, A., 2008. On SARS Type Economic Effects during Infectious Disease Outbreaks. World Bank Policy Research Paper No. 4466, World Bank, Washington, D.C. https://openknowledge.worldbank.org/handle/10986/6440

Carter, C.A. Steinbach, S., 2020. The Impact of Retaliatory Tariffs on Agricultural and Food Trade (No. w27147). National Bureau of Economic Research.

https://www.nber.org/papers/w27147\#: :text=The $\% 20$ results $\% 20$ indicate $\% 20$ that $\% 20$ these,reori entation $\% 20 \mathrm{of} \% 20$ international $\% 20$ trade $\% 20$ patterns.

Chenarides, L., Mark M., Richards, T.J., 2020. —COVID-19 and Food Supply 
Chains. Applied Economic Perspectives and Policy. 43(1), 270-279.

doi.org/10.1002/aepp.13085.

Crowley, M. A. 2019. Trade War: The Clash of Economic Systems Threatening Global Prosperity. London: CEPR Press. https://voxeu.org/content/trade-war-clash-economic-systems-threateningglobal-prosperity

Evenett, S., Fiorini, M., Fritz, J., Hoekman, B., Lukaszuk, P., Rocha, Ruta, M., Santi, F., Shingal, A., 2021. Trade policy responses to the COVID-19 pandemic crisis: Evidence from a new data set. The World Economy (forthcoming).

Fajgelbaum, P. Khandelwal, A., Kim, W., Mantovani, C., Schaal, E., 2020. Optimal Lockdown in a Commuting Network, NBER Working Paper No. 27441, https://www.nber.org/papers/w27441

FAO, IFAD, UNICEF, WFP, WHO. 2021. The State of Food Security and Nutrition in the World 2021. Transforming food systems for food security, improved nutrition and affordable healthy diets for all. Rome, FAO. https://doi.org/10.4060/cb4474en

Friedt, F., Zhang, K., 2020. The Triple Effect of COVID-19 on Chinese exports: First Evidence of the Export Supply, Import Demand and GVC Contagion Effects. Center for Economic Policy Analysis, Covid Economics: Vetted and Real Time Papers. https://www.econbiz.de/Record/thetriple-effect-of-covid-19-on-chinese-exports-first-evidence-of-the-export-supply-import-demandand-gvc-contagion-effects-friedt-felix/10012311905

Grant, J., Arita, S., 2017. Sanitary and Phyto-sanitary measures: Assessment, measurement, and Impact (No. 938-2017-1828). https://iatrc.umn.edu/sanitary-and-phyto-sanitary-measuresassessment-measurement-and-impact

Grant, J.H., Arita, S., Emlinger, C., Johansson, R., Xie, C. 2021. Agricultural Exports and Retaliatory Trade Actions: An Empirical Assessment of the 2018/2019 trade conflict. Applied Economics Perspectives and Policy 43(2), 619-640. https://doi.org/10.1002/aepp.13138

Head, K. Mayer, T., 2014. Gravity equations: Workhorse, toolkit, and cookbook. In Handbook of international economics (Vol. 4, pp. 131-195). Elsevier. https://doi.org/10.1016/B978-0-444$\underline{54314-1.00003-3}$

International Monetary Fund (IMF). 2020. —World Economic Outlook Update, June 2020. Available online: https://www.imf.org/en/Publications/WEO/Issues/2020/06/24/WEOUpdateJune2020

International Monetary Fund, 2021. World Economic Outlook: Managing Divergent Recoveries: https://www.imf.org/en/Publications/WEO/Issues/2021/03/23/world-economic-outlook-april2021. 
Kejzar, K.Z. Velic, A. 2020. COVID-19, Trade Collapse, and GVC Linkages: European Experience. Center for Economic Policy Analysis, Covid Economics: Vetted and Real Time Papers, https://cepr.org/content/covid-economics-vetted-and-real-time-papers-0

Luckstead, J., Nayga Jr, R. M., Snell, H. A., Labor Issues in the Food Supply Chain Amid the COVID-19 Pandemic. Applied Economic Perspectives and Policy. 43(1), 382400. doi.org/10.1002/aepp.13090.

Lusk, J. L., Tonsor, G. T., Schulz, L., 2021. Beef and Pork Marketing Margins and Price Spreads during COVID-19. Applied Economic Perspectives and Policy. 43(1), 4-23. doi.org/10.1002/aepp.13101

Mallory, M. L. 2020. Impact of COVID-19 on Medium-Term Export Prospects for Soybeans, Corn, Beef, Pork, and Poultry. Applied Economic Perspectives and Policy. 43(1) 292-303. doi.org/10.1002/aepp.13113.

Ning, X. Grant, J.H., 2019. New Estimates of the Ad-valorem Equivalent of SPS Measures: Evidence from Specific Trade Concerns. https://vtechworks.lib.vt.edu/handle/10919/95217

Peterson, E., Grant, J., Roberts, D. Karov, V., 2013. Evaluating the Trade Restrictiveness of Phytosanitary Measures on US Fresh Fruit and Vegetable Imports. American Journal of Agricultural Economics, 95(4), 842-858. https://onlinelibrary.wiley.com/journal/14678276.

Reuters, 2020. Rain to help EU Rapeseed but too late to Avert French Area Drop. October 2, 2020, available at:

https://www.reuters.com/article/us-europe-grains-sowing/rain-to-help-eu-rapeseed-but-too-lateto-avert-french-area-drop-idUSKBN26N27F

Santos S., J.S. Tenreyro, S., 2006. The Log of Gravity. The Review of Economics and statistics, 88(4), 641-658. https://direct.mit.edu/rest/article/88/4/641/57668/The-Log-of-Gravity

Ahn, S., Steinbach, S., 2021. COVID-19 Trade Actions in the Agricultural and Food Sector. Food Distribution Research Society, 52(2), 51-75. https://www.fdrsinc.org/wpcontent/uploads/2021/09/JFDR-July-2021-Full-Issue.pdf\#page=55

United Nations Conference on Trade and Development (UNCTAD), 2016. Key Indicators and Trends in International Trade 2016. https://unctad.org/en/PublicationsLibrary/ditctab2016d3_en.pdf

World Bank, 2021. Global Economic Prospects. World Bank Global Economic Prospects Report, January, Available at: https://www.worldbank.org/en/publication/global-economicprospects

World Trade Organization (WTO). 2020a. Methodology for the WTO Trade Forecast of April 8 2020. https://www.wto.org/english/news e/pres20 e/methodpr855 e.pdf 
World Trade Organization (WTO). 2020b. COVID-19 and Agriculture: A Story of Resilience. Information Note. August 26, 2020. https://www.wto.org/english/tratop e/COVID-

19 e/agric report_e.pdf

World Trade Organization (WTO). 2021. World Trade Primed for Strong but Uneven Recovery after COVID-19 Pandemic Shock. Press Release. March 31, 2021.

https://www.wto.org/english/news_e/pres21_e/pr876_e.pdf

Yaffe-Bellany, D., and Corkery, M. 2020. Dumped Milk, Smashed Eggs, Plowed Vegetables: Food Waste of the Pandemic. New York Times, April 11, 2020. Available at:

https://www.nytimes.com/2020/04/11/business/coronavirus-destroying-food.html

Yotov, Y.V., Piermartini, R., Monteiro, J.A. and Larch, M., 2016. An Advanced Guide to Trade Policy Analysis: The Structural Gravity Model. Geneva: World Trade Organization. Available at:

https://www.wto.org/english/res_e/booksp_e/advancedwtounctad2016_e.pdf 